\title{
The Role of the Project Manager in Construction Projects in India
}

\author{
Abdussalam Shibani, Denish Sukumar \\ Coventry University, Coventry, England
}

In India, the construction industry plays an important role in the economy of the country. It employs a sizeable portion of the work force, contributes largely to the gross domestic product (GDP) of the country, and is seen as a key catalyst for the growth and development of the Indian economy. The industry, however, is beset with many challenges, including delivering projects within projected costs and delivery dates and at the right quality to increasingly discerning clients. It is because of this that project management has assumed so much importance with the project manager seen to be a critical resource in the project achieving its objectives. However, the role of the project manager is still ambiguous. These research hypotheses that the role the project manager ought to play is that of a leader. It is only when project managers assume leadership roles that construction projects achieve objectives measured against time, cost, quality, and customer satisfaction. A quantitative approach was followed in this using both theoretical and analytic methods. The theoretical studies revealed the qualities, skills, and competencies that a project manager ought to possess and the links between the project manager assuming a position of leadership and the project achieving its objectives. The main data collection tool in the analytic method was an online questionnaire administered to 20 project managers of construction projects in India. It was found that while the Indian construction industry does recognize the significance of project managers, their role is relegated to administrative, monitoring, and supervision tasks. There is an overwhelming focus on technical skills. In those cases, where project managers were involved in all the stages of the project and possessed a gamut of managerial, technical, human, and interpersonal skills, there were substantial differences in terms of time, cost, quality, and customer satisfaction in the projects administered by them. The importance of this research stems from its alerting the construction sector in India to the true role that project managers ought to play. If it serves in a shift in the perception of the role of the project managers, this research would have served its purpose.

Keywords: India, managerial, gross domestic product (GDP), technical skills

\section{Introduction}

The construction industry in India plays an important role in the economy of India. After agriculture, it is the second largest industry in the country and is an important employment generator as well (Kamara, 2012). It is a highly diversified industry spread out across infrastructural projects including highways and airports,

Abdussalam Shibani, Ph.D., lecturer, civil engineering architecture and building, Coventry University, Coventry, United Kingdom.

Denish Sukumar, M.Sc. student in construction, project, and cost management, Coventry University, Coventry, United Kingdom.

Correspondence concerning this article should be addressed to Abdussalam Shibani, Coventry University, Priory Street, Coventry, CV1 2FB, United Kingdom. E-mail: ab1732@coventry.ac.uk. 
commercial spaces including offices and malls, residential apartments and houses, as well as industrial factories and mills. The decades post 1990 ushered in an era of liberalization in the country which has resulted in the mushrooming of several IT parks, special economic zones, large malls, and residential complexes. These requirements gave an enormous boost to the real estate sector. A measure of the demand is the fact that there is still a shortage of residential and office space (Sabol, 2009). Despite rapid strides in infrastructural developments, there is still a shortage of adequate infrastructure to take care of the needs of India's growing population and industry (Sabol, 2009). It is apparent that in a developing country like India, the future appears bright for the building and construction industry. Indeed so important is this sector that the government has targeted investing $\$ 500$ bn in infrastructural projects alone during the decade from 2010 to 2020 (Grover \& Somaya, 2011).

Currently, the sector is facing many challenges. It is a highly fragmented industry with only $0.4 \%$ of the total quarter of a million construction firms in the country being categorized as medium to large firms (Grover \& Somaya, 2011). The rest of the firms come under the unorganized sector. According to research conducted by Deming (2012), it is deeply fragmented with a very low rate of profitability. At less than $10 \%$, the margins are too low to be sustainable. Egan (2012) said that there is little investment in research and development which means that the latest innovations are in processes and technologies do not get incorporated in construction projects.

\section{Critical Success Factors for Construction Projects}

An analysis of the literature regarding critical success factors for construction projects only underscores the confusion and ambiguity that prevails on the subject. Hills, Fox, Fong, and Skitmore (2011) said that planning and control techniques are most important. These views were corroborated by Deming (2012) who stated that improved scheduling techniques, monitoring, and control mechanisms positively impact construction projects. Brown, Dillard, and Marshall (2012) and Arditi and Gunaydin (2011) also considered the aforementioned aspects as being critical but also added feedback, review, project philosophy, organization, resource allocation, and project team selection and composition as other critical success factors. Austin and Thompson (2012) identified a list of critical success factors for construction projects, including client characteristics, training, manpower competencies, management of labour, finance, and logistics. Brezet (2012) considered that management of information and transparency of communication channels are critical factors. Chua, Kog, and Loh (1999) said that cost estimation, budgeting, and adequate project funding are most important and they also add project team qualification and competence as additional factors.

Eckbald and Ashcraft (2013), in their analysis of several building projects in the United States and in India, identified setting of clear project goals and open channels of communication as critical success factors. Hewage and Ruwanpura (2009) singled out project scope as determining project duration and hence impacting project success. Piselli (2011) added to the scope, project complexity and size as other determining factors. Saaty (1999) considered management of procurement and tendering processes, including selection of contractors, sub-contractors, consultants, suppliers, and vendors to be critical factors. Womack and Jones (2012) focused on the influence of client on project results. They also said that clients have the power to critically influence and make changes in projects and hence client management was most important. Tulke, Nour, and Beucke (2012) said that environmental factors have the greatest influence on project management. These include social, political, and technical factors including funding, site, and location management to which industrial management added. Shen, V. Tam, C. M. Tam, and Drew (2012) considered allocation of sufficient resources 
while believed flexibility and change management as critical success factors.

It may be noted from the above that these views summarize common understanding of critical success factors of construction factors. An analysis of other literature indicates the shift towards consideration of project management as the most important critical success factor in addition to all of the above. Teo and Loosemore (2011) identified four critical factors related to projects. These include project management, project manager, organization, and the external environment. Project management was related to size of projects, its life cycles, competencies and skills of project members, support of top management, organizational structure and political, economic, social, and technological issues. Paritosh (2009) believed project management to be the single biggest factor in ensuring success of a project, combining planning and control, organizational structure, management action, quality control, and safety management. The latest view is that of Sami Consulting (2013) who identified project management as the most important critical success factor in construction projects and considered project management to be composed of strategy, people, process, schedules, resource and budget allocation and management of risk, tools, standards, and procedures.

It may be inferred from the above that project management has assumed critical importance in ensuring success of construction projects with the project manager playing an important role. Figure 1 indicates typical construction project activities without a project manager and the multiple tasks the construction agency has to undertake without a project manager to complete the work (Bubshait \& Al-Atiq, 2011).

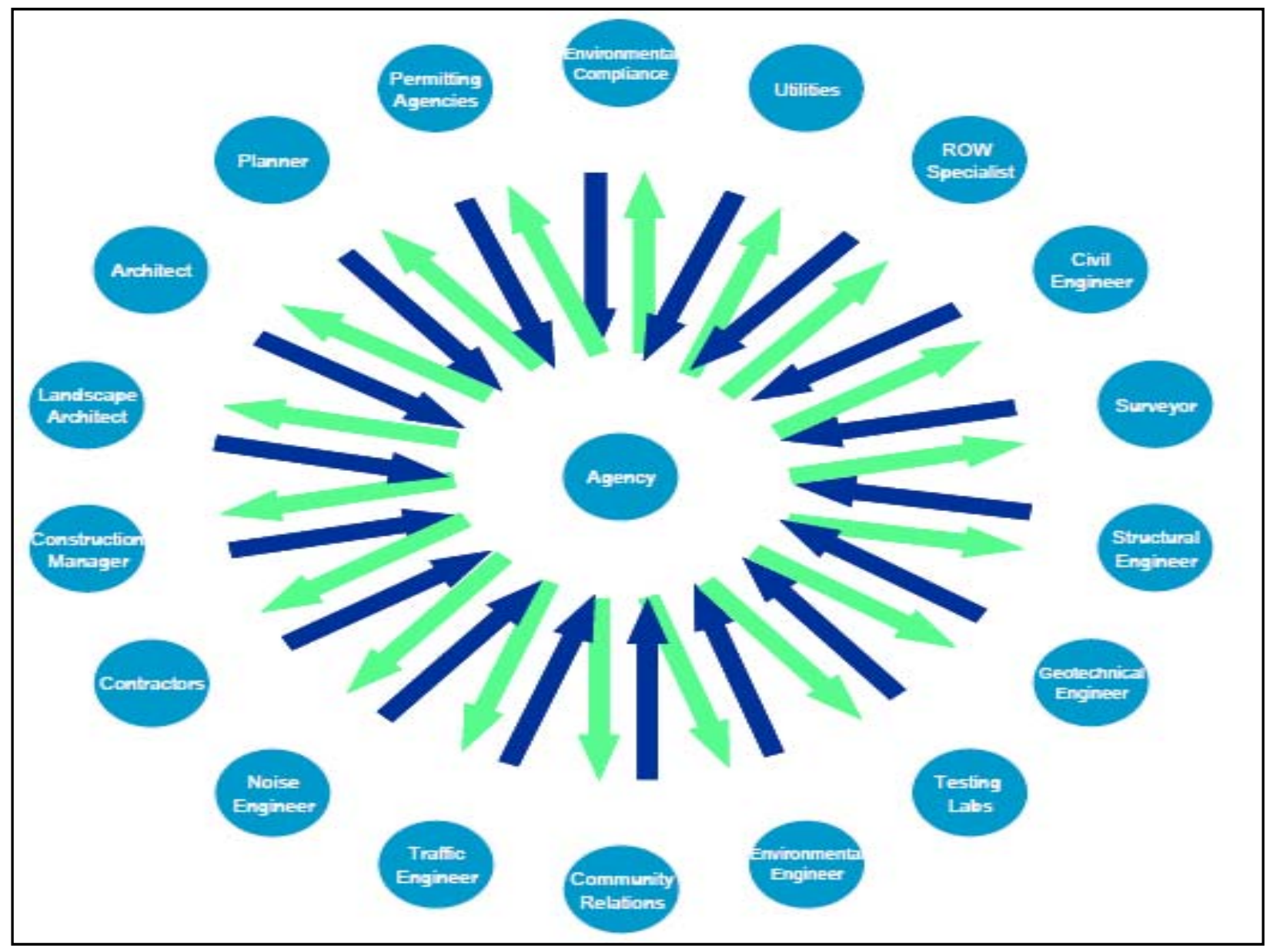

Figure 1. Construction project without a project manager. Source: Sabol (2009). 
Conversely Figure 2 indicates how tasks in a construction project get streamlined and structured with a project manager to manage flow of activities.

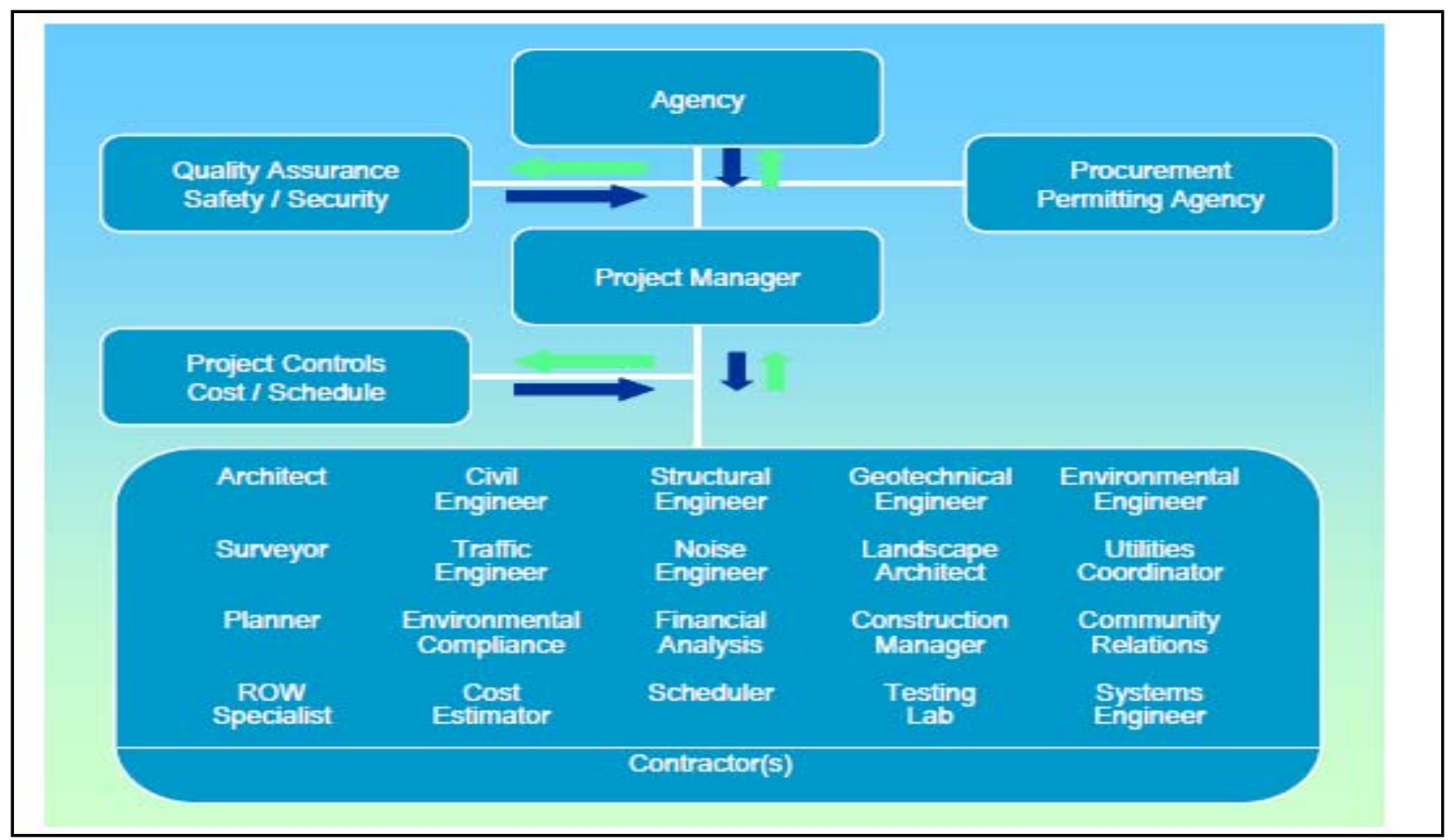

Figure 2. Construction project with a project manager. Source: Sabol (2009).

\section{Role of the Project Manager}

Just like in project management, there is considerable ambiguity about the role of the project manager in construction projects. Jha (2013) said that the main role of a project manager is in the preconstruction stage where planning is the key task. Here the main role of the project manager is the preparation of deliverable schedule in accordance with client bid, drawing up the preliminary construction schedule, delineating project requirement, allocation of resources, plan review, and goal setting. Hopp and Spearman (2011) and Burdge and Robertson (2009), however, differed from this view and stated that the main role of the project manager is in the administration of the project. Here the project manager manages the clients, communicates issues, co-ordinates activities, and manages information flow. Egan (2012) believed that project managers' main role is in making acquisitions required for the construction of the project, including consistent refining the project scope, identification of items that have delivery dates which impact the schedule, procurement, and purchasing of materials. De Ridder and Vrijhoef (2013) pointed out that project managers should concern themselves solely with the management and scheduling of projects including understanding of manpower operations, applications of materials, issuance of building code, and site logistics management (CIRIA, 2013).

\section{Communication}

Formoso and Soibelman (2012) said that project managers in construction projects act as a liaison among several agents. This is also indicated in Figure 2. Therefore, leaders must have good communication skills. Drucker (2010) said that decision-making abilities, intelligence, and communication skills are essential traits of any leader. Communication refers to the ability of project managers to listen, understand, and persuade others. 
Exchange of information determines effectiveness of communication which Greenwood, Jones, and Snow (2013) defined as the act of transmitting information either verbally or in written form. Bunn and Smith (2013) corroborated this view, when they stated that project managers should have good writing, oral, and listening skills.

\section{Empowerment}

According to Barnes (2011), empowering of project managers is critical for them to assume leadership position, because they then do not play the roles of implementers or managers only, but also take decisions and delegate authority. They have an enhanced role to play in the control and distribution of resources and give them more freedom and flexibility of action. By empowering project managers, project standards can be enforced, discipline maintained, and all aspects of the project appropriately monitored.

\section{Influencing}

Project managers must have the ability to influence other team members in a very personal way. Bresnen and Marshall (2011) believed one of the ways of influencing other team members is in the form of feedback provided to subordinates. Dave, Koskela, Kagioglou, and Bertelsen (2012) recommended frequent site visits, indicating interest, concern, and appreciation for performance in order to increase morale, loyalty, and a sense of belonging to the project or team. It is through this influence that standards for the work and key expectations may be communicated appropriately through all levels of the project.

\section{Team Building}

According to Kwakye (2012), project managers have to have the ability to build teams. Team building is essential to make everyone in the team understand why decisions have been taken and communicate key expectations, foster learning, and knowledge sharing. Love and Smith (2013) recommended following the Xerox model which includes: (a) communication of vision; (b) development of a mission statement; (c) definition of goals; (d) development of norms; (e) development of roles; (f) development of communication processes; and (g) development of work processes. McDonald and Smithers (2012) believed team building to be key to removing barriers to proper collaborative working. Rischmoller and Alarcon (2011) said that team building decreases friction amongst team members and ensures proper selection of persons who will work together for the success of the project.

\section{Problem-Solving Skills}

Problem solving refers to the ability to analyze adverse conditions and sources of conflict, identify practical solutions, and then implement them. Problem-solving skills are essential for any project manager, particularly in construction projects, where eruption of problems across the project life cycle is routine. According to Skoyles (2011) and Crittenden (2012), project managers who are also leaders must have the ability to make informed judgments where they use data and experience to draw conclusions and make decisions that lead to the solution of problems when they arise.

\section{Conflict Resolution}

Wand and Hannafin (2012) defined conflicts as differences of ideas, beliefs, and opinions on any particular point and that conflict resolution is a key leadership trait to be developed in a project manager. This is because of the frequency of occurrence of conflicts in construction projects. A conflict results in the breaking of personal and professional relationships, creates tension, reduces effectiveness of the team, and ultimately leads to compromise in goals of the construction project. 


\section{Planning and Goal Setting}

One of the key leadership skills that project managers in construction projects need to develop is planning and goal setting. Planning is the ability to set goals and then formulate action steps to achieve that goal. Turner (2012) in fact considered planning to be the creating expression of a leader.

\section{Visioning}

One of the points of difference between project managers and project managers who are also leaders is the ability to develop a vision for the entire project. It is said that a vision is necessary to set goals and chart the course of action for the project including creation of strategies that lead to the achievement of this vision. It aids in describing what an organization or projects wants to achieve.

\section{Sense of Responsibility}

A keen sense of responsibility is another essential feature of the leader project manager. This sense of responsibility is directed towards the team, its performance and the project managers own performance, the overall success of the project, working within budgets, time schedules, quality, and safety requirements.

\section{Ethics}

Project managers are also moral beings who take morally correct decisions. Such behavior then governs the conduct of other individuals in the projects. Hence abiding by a set of professional ethics and norms is critical in project management (Saaty, 1999). Ethical behavior translates into business benefits as well, including proper cost management, maintenance of quality and competitiveness, as well as creation of customer satisfaction.

\section{Initiative}

Project managers who take initiative are also leaders. This taking of initiative is key to the identification of new ideas, procedures, sharing of ideas, resolution of problems, and in overcoming obstacles (Schonberger, 2009). It refers to the ability to foresee and pre-empt events and problems before they occur.

\section{Time Management}

Effective time management is essential to control time and to finish various tasks according to set deadlines. Effective time management is actually reducing overall time of the project with no compromise in quality or cost of the project and is a key trait of a good leader (Abdel-Razek, 2012).

\section{Monitoring}

Monitoring is one of the critical tasks of any project manager and involves observing work progress, collection and evaluation of information and using such information to take corrective measures wherever necessary to enhance performance. Effective monitoring results in completion of the project within budget, within timelines, and at desired quality levels as well (Berends, 2007).

\section{Positivity}

Rischmoller and Alarcon (2011) saw a clear link between positivity and success of the project. Positivity refers to respect for a person's dignity and self worth. It includes appreciation for work well done. A project manager who is able to create such feelings in their team members is also a leader who leads the team on to the achievement of specific objectives.

\section{Personal Traits}

Apart from technical qualifications and experiences, project managers must also possess personal traits that lead on to leadership. Motete, Mbachu, and Nkado (2011) said that self confidence, self awareness, 
flexibility, honesty, integrity, quick thinking, persistence, intelligence, creativity, and the ability to conceptualize are some of the most important traits.

\section{Research Methodology}

All research methodologies can be classified as qualitative and quantitative. Qualitative research is based on theoretical study and is used to identify patterns, themes, or recurring features in a mass of data. Quantitative studies are based on precise measurements and experiments and are used to identify statistical relationships among a set of variables. Qualitative studies use a process of exploration to construct and explain hypotheses. Conversely, quantitative studies use mathematical models and calculations to predict possible outcomes (Zikmund, Babin, Carr, \& Griffin, 2010).

According to Wegner (2010), qualitative methods are best employed when explaining social phenomena. It is a research that deals with subjective assessment of attitudes, opinions, and behavior. Research in such a situation is a function of researcher's insights and impressions. As such, it can be subject to bias, prejudice of the interpreter. Such an approach to research generates results either in non-quantitative form or in the form which is not subjected to rigorous quantitative analysis.

According to Zikmund et al. (2010), quantitative research is based on numbers and statistics. It is used to test hypotheses, look at cause and effect, and make predictions. It is used to identify statistical relationships between variables and yields objective results.

The quantitative method has been employed in this research, since it is based on precise measurements and statistical analysis which yield results that are objective and hence more credible. These results can hence be generalized to all construction companies in India. The quantitative method used in this research uses both descriptory and analytic techniques.

\section{The Descriptory Technique}

In the descriptory technique, facts or information already available are first analyzed to make a critical evaluation of the material. Descriptory research relies on secondary research that has already been conducted in the past. By collating the results of secondary data about a particular problem, fresh insights might be obtained. Descriptory research is based on theoretical study and is used to identify patterns, themes, or recurring features in a mass of data. In this research, the descriptory method has been used to construct the literature review to identify how the role of the project manager has been perceived in construction projects in India.

During this research, the sources of secondary data used by the author included business journals, books and publications, as well as the Internet. As far as possible, only peer reviewed articles and journals were used. The data set may therefore be considered to be reliable and valid.

The broad hypotheses that emerge from the literature review are formulated below:

H1: The more the project manager of construction projects assumes a leadership role, the timelier the project deliveries;

H2: The more the project manager of construction projects assumes a leadership role, the more cost efficient the project has;

H3: The more the project manager of construction projects assumes a leadership role, the better the quality of the project is;

H4: The more the project manager of construction projects assumes a leadership role, the more 
productivity of the project is;

H5: The more the project manager of construction projects assumes a leadership role, the more the turnover, profitability, and market share of the construction firm are.

It may be noted that the above are only hypotheses. They have to be validated by the analytic method.

\section{The Questionnaire}

The questionnaire formed the main data collection tool. The questionnaire consisted of 20 close ended questions administered to the project managers of 20 construction projects in India. Close ended questions yield objective answers that can be used for statistical analysis. Hence in the interest of obtaining objective results and reducing ambiguity, close ended questions were chosen. Participants could answer the questionnaire based on a four-point Liker scale. Their preferred choice of answer could be represented by a number one to four which when collated together could be used for statistical analysis. The questionnaire administered to the project managers would evaluate the role they played in their respective projects and what bearing their role have on the effectiveness of the project.

The questionnaire was used as the primary data collection instrument as it offers several advantages. According to Hague (1987), a questionnaire is the quickest, most economical, and practical method of gathering information. This is especially so, when compared to personal interviews or focus groups. The questionnaire can be answered at the convenience of the respondents. Moreover, the respondents can answer it without disclosing their identities. This will encourage disclosure of information in a frank and uninhibited manner, eliminating errors that occur due to prejudice or bias of the respondents.

\section{Phone Interview}

A questionnaire is administered only once to collect a main data set. However, the author at times encountered doubts whilst perusing the questionnaire or wanted more clarifications. For these purposes, a phone interview was used. The author called up the respondents on their phone numbers to clarify any doubts. The phone interview method was used instead of a personal interview, as it is far more convenient to clear doubts and it is quick, flexible, and cheap. It also does not bring personal presence or inconvenience to the respondents.

The questionnaire used to interview the respondents consists of the following sections-demographics. It consists of three questions which queried on the tenure of respondents in current organization, total experience as project manager and educational qualifications. The main purpose of these questions was to analyze the kind of professionals that construction companies in India utilize as project managers.

\section{Data Analysis}

\section{Section A-Demographics}

This section explores the demographic profile of the respondents.

Tenure. It can be seen from Figure 3 that of the 20 respondents, 18 have tenure of more than five years with the remaining two having tenure of three to five years.

Experience. From Figure 4, it can be seen that all the respondents have experience of more than 20 years in project management in the construction industry.

Qualifications. From Figure 5, it is evident that all the respondents are well qualified. Sixteen of the 20 have an engineering degree while the other four are graduates. Sixteen have post graduate degrees in management while the other four have post graduate technical qualifications. 


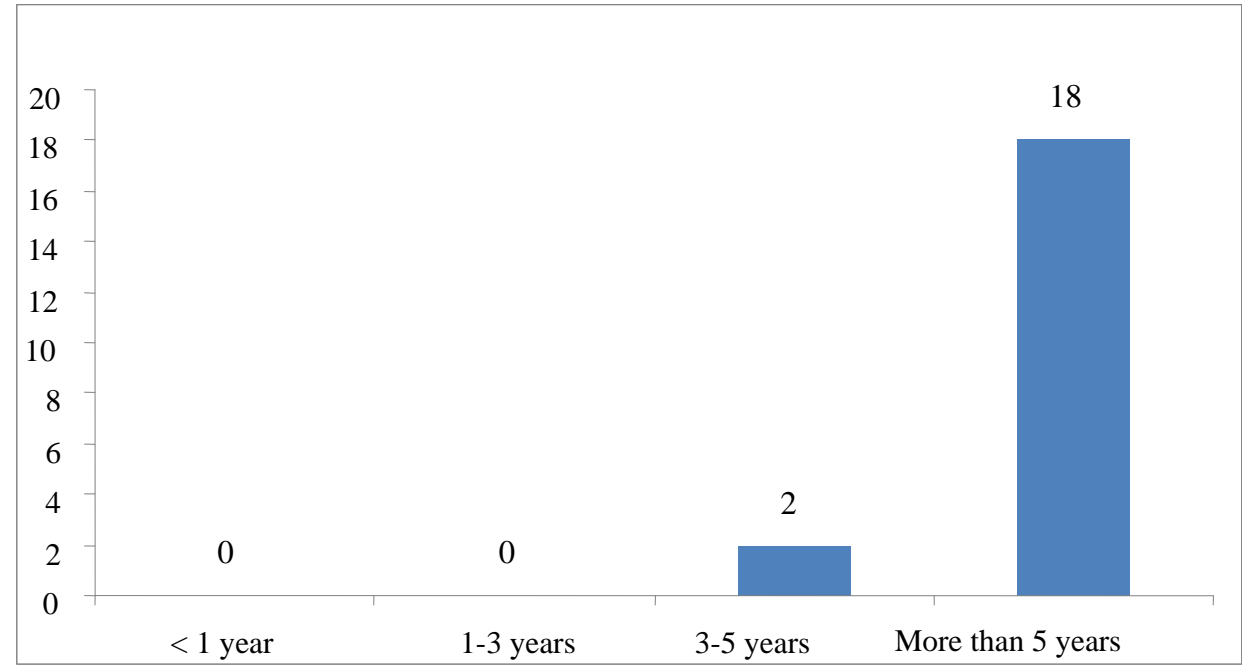

Figure 3. Tenure with current organization.

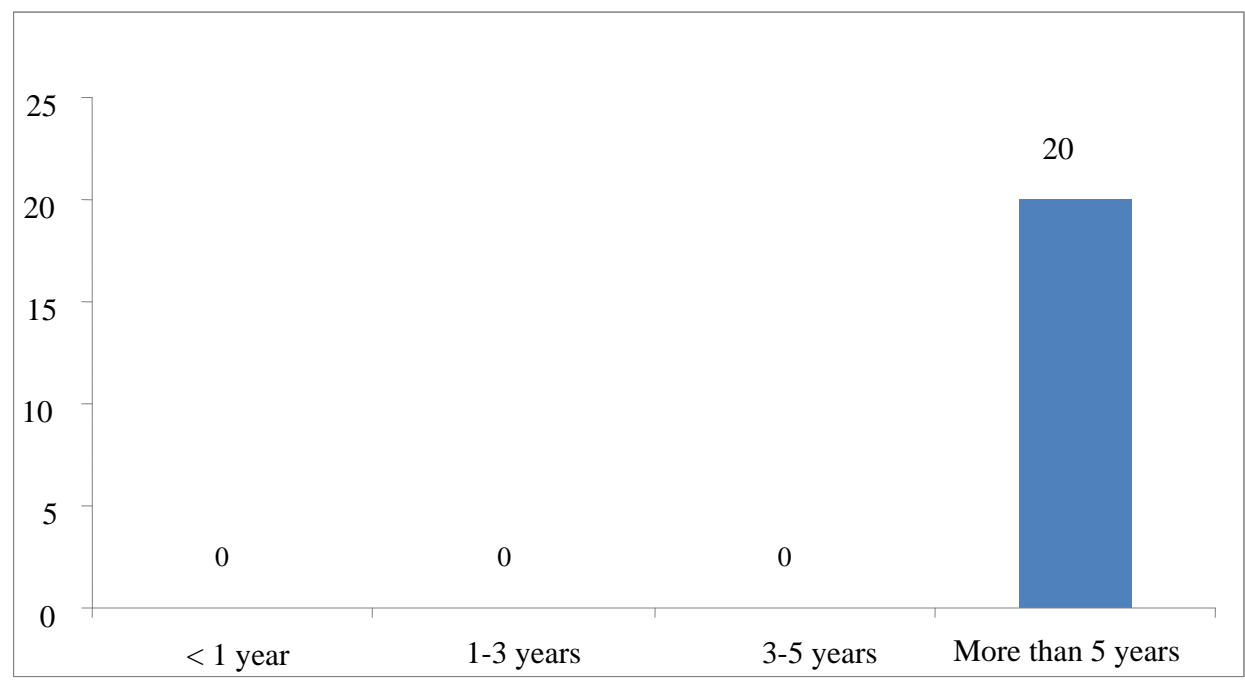

Figure 4. Experience as project manager.

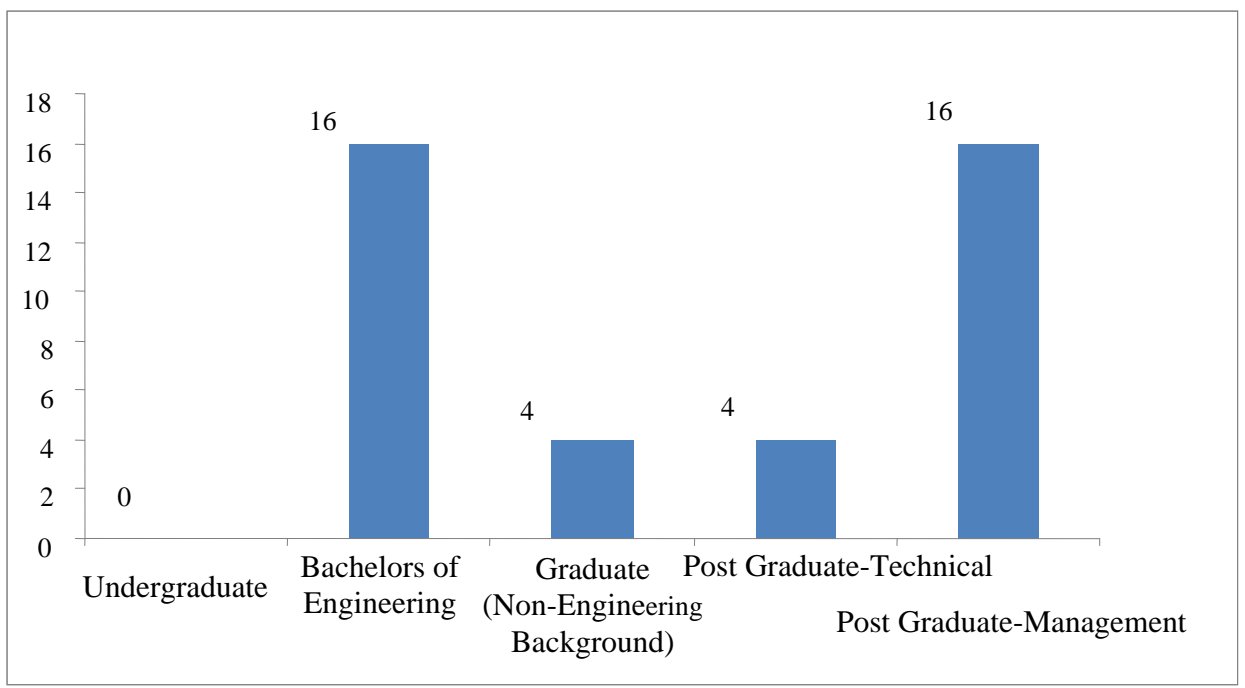

Figure 5. Qualifications. 
An analysis of the demographics of the respondents indicates that all are well qualified professionals with long tenure in their organizations and experience as project managers in construction management. It indicates that even in a developing country like India, project management is a task assigned to professional persons. The implications for this research are that their views will be more accurate and relevant and this will yield objective and valid results.

\section{Section B-The Role of the Project Manager}

This section explores how the project managers view themselves and what is their role as project managers in construction sites in India.

Challenges in Indian construction industry. From Table 1, it is evident that many of the challenges that one would have assumed as being critical to the construction industry have in fact not being named as being so. This includes weak consumer demand, lack of manpower, lack of finance, and a weak global economy. This points to burgeoning construction projects in India which, as was identified in mentioned section, is witnessing a construction boom. What has however been rated as critical is lack of systems and processes, cost overruns, untimely completion, waste of money, time, resources, conflicts between end clients and construction firms, achieving customer satisfaction, and high competition. These findings are corroborated with those of the mentioned section which identified achieving client satisfaction as the most important challenge in the construction industry. Moreover, the Indian construction sector is highly fragmented, with projects being plagued with cost overruns, untimely construction schedules, defects, and poor crisis management.

Table 1

Challenges in Indian Construction Industry

\begin{tabular}{|c|c|c|c|c|c|c|}
\hline & $\begin{array}{l}\text { Most } \\
\text { important: } 4 \\
\end{array}$ & Important: 3 & $\begin{array}{l}\text { Moderately } \\
\text { important: } 2 \\
\end{array}$ & $\begin{array}{l}\text { Unimportant } \\
: 1\end{array}$ & $\begin{array}{l}\text { Weighted } \\
\text { average }\end{array}$ & Interpretation \\
\hline Government bureaucracy & 3 & 17 & 0 & 0 & 3.2 & Important \\
\hline Lack of sources of finance/capital & 0 & 0 & 16 & 4 & 1.8 & Moderately important \\
\hline Weak consumer demand & 0 & 0 & 4 & 16 & 1.2 & Unimportant \\
\hline Very high competition & 17 & 3 & 0 & 0 & 3.9 & Most important \\
\hline Lack of manpower & 0 & 0 & 2 & 18 & 1.1 & Unimportant \\
\hline Lack of systems and processes & 18 & 2 & 0 & 0 & 3.9 & Most important \\
\hline Cost overruns & 17 & 3 & 0 & 0 & 3.9 & Most important \\
\hline Weak global economy & 0 & 0 & 17 & 3 & 1.9 & Moderately important \\
\hline Non-completion of projects on time & 20 & 0 & 0 & 0 & 4.0 & Most important \\
\hline Waste of time, money, resources & 18 & 2 & 0 & 0 & 3.9 & Most important \\
\hline Achieving customer satisfaction & 19 & 1 & 0 & 0 & 4.0 & Most important \\
\hline $\begin{array}{l}\text { Conflict between customers and } \\
\text { project owners }\end{array}$ & 18 & 2 & 0 & 0 & 3.9 & Most important \\
\hline
\end{tabular}

From the mentioned section, it was identified that it was precisely in recognition of these challenges that project management has assumed such significance in the construction industry even in India, just like in the rest of the world with project managers playing a key role in the management of construction projects. However, just what role they play and what is their effectiveness in the outcomes of construction projects in terms of time, cost, quality, and customer satisfaction in India, have not been explored in the literature. It is this gap that this research seeks to cover.

Project managers as leaders. The respondents were queried whether they considered themselves to be leaders or not. Tables 2 and 3 summarize their results. 
Table 2

Project Managers Who Consider Themselves as Leaders

\begin{tabular}{|l|l|}
\hline \multirow{2}{*}{$\begin{array}{l}\text { Group A: } \\
\text { Project managers who regard themselves as leaders }\end{array}$} & Project manager 7 \\
\cline { 2 - 2 } & Project manager 11 \\
\cline { 2 - 2 } & Project manager 12 \\
\hline
\end{tabular}

Table 3

Project Managers Who Do Not Consider Themselves as Leaders

\begin{tabular}{|l|l|}
\hline \multirow{5}{*}{\begin{tabular}{|l|} 
Group B: \\
Project managers who do not regard themselves as leaders
\end{tabular}} & Project manager 1 \\
\cline { 2 - 2 } & Project manager 2 \\
\hline & Project manager 3 \\
\hline & Project manager 4 \\
\hline & Project manager 5 \\
\hline & Project manager 6 \\
\hline & Project manager 8 \\
\hline & Project manager 9 \\
\hline & Project manager 10 \\
\hline & Project manager 13 \\
\hline & Project manager 14 \\
\hline & Project manager 15 \\
\hline & Project manager 16 \\
\hline & Project manager 17 \\
\hline & Project manager 19 \\
\hline & Project manager 20 \\
\hline
\end{tabular}

From Table 2, it can be seen that of the 20 respondents, only four consider themselves as leaders. These have been termed as Group A while the remaining 16 respondents who did not consider themselves as being leaders have been termed Group B. The rest of the questionnaire analysis will examine the responses of both these groups separately.

From the literature review, it was identified that construction projects may be divided into four stages. These include the formulation, conceptualization, execution, and completion stages. The following four questions will examine whether the project managers are involved in all the stages or if their use is relegated to some stages of construction only.

Involvement in the formulation stage of construction projects. Table 4 indicates the responses of the Group A managers.

From Table 4, it can be seen that all the respondents strongly disagree that they are not involved in the initial formulation stages of the construction project. All the other parameters that go into the initial stages of any construction project, such as tender evaluation, selection of bids, preparation of bid schedules, marketing, vendor finalization, etc., attract strong involvement from all the Group A managers.

Table 5 indicates the response from the Group B managers.

From Table 5, it is apparent that the Group B set of project managers are not involved in any way in the initial formulation stage of the construction projects. It is evident that these tasks fall under the purview of respective departments, such as estimation, procurement, and marketing with the project managers not being involved at this stage of the project. 
Table 4

Formulation Stage-Group A

\begin{tabular}{|c|c|c|c|c|c|c|}
\hline Group A & $\begin{array}{l}\text { Strongly } \\
\text { agree: } 4\end{array}$ & Agree: 3 & Disagree: 2 & $\begin{array}{l}\text { Strongly } \\
\text { disagree: } 1\end{array}$ & $\begin{array}{l}\text { Weighted } \\
\text { average }\end{array}$ & Interpretation \\
\hline $\begin{array}{l}\text { Interface with customers to } \\
\text { understand their requirements }\end{array}$ & 3 & 1 & 0 & 0 & 3.8 & Strongly agree \\
\hline Calling for bids/tender & 1 & 0 & 3 & 0 & 2.5 & Agree \\
\hline Evaluation of tenders & 3 & 1 & 0 & 0 & 3.8 & Strongly agree \\
\hline Selection of bids/tender & 2 & 2 & 0 & 0 & 3.5 & Strongly agree \\
\hline $\begin{array}{l}\text { Marketing of company, its } \\
\text { competencies and offerings }\end{array}$ & 4 & 0 & 0 & 0 & 4.0 & Strongly agree \\
\hline $\begin{array}{l}\text { Assisting the estimating department } \\
\text { during plan review }\end{array}$ & 3 & 1 & 0 & 0 & 3.8 & Strongly agree \\
\hline $\begin{array}{l}\text { Preparing a deliverable schedule } \\
\text { relative to bidding practices }\end{array}$ & 4 & 0 & 0 & 0 & 4.0 & Strongly agree \\
\hline $\begin{array}{l}\text { I am not involved in the formation } \\
\text { stage of the construction project }\end{array}$ & 0 & 0 & 0 & 4 & 1.0 & Strongly disagree \\
\hline $\begin{array}{l}\text { Finalization and selection of } \\
\text { vendors/supplier }\end{array}$ & 4 & 0 & 0 & 0 & 4.0 & Strongly agree \\
\hline
\end{tabular}

Table 5

Formulation Stage-Group B

\begin{tabular}{|c|c|c|c|c|c|c|}
\hline Group B & $\begin{array}{l}\text { Strongly } \\
\text { agree: } 4\end{array}$ & Agree: 3 & Disagree: 2 & $\begin{array}{l}\text { Strongly } \\
\text { disagree: } 1\end{array}$ & $\begin{array}{l}\text { Weighted } \\
\text { average }\end{array}$ & Interpretation \\
\hline $\begin{array}{l}\text { Interface with customers to } \\
\text { understand their requirements }\end{array}$ & 0 & 5 & 8 & 3 & 2.1 & Disagree \\
\hline Calling for bids/tender & 0 & 0 & 0 & 16 & 1.0 & Strongly disagree \\
\hline Evaluation of tenders & 0 & 2 & 0 & 14 & 1.3 & Strongly disagree \\
\hline Selection of bids/tender & 0 & 0 & 0 & 16 & 1.0 & Strongly disagree \\
\hline $\begin{array}{l}\text { Marketing of company, its } \\
\text { competencies and offerings }\end{array}$ & 0 & 0 & 14 & 2 & 1.9 & Disagree \\
\hline $\begin{array}{l}\text { Assisting the estimating department } \\
\text { during plan review }\end{array}$ & 0 & 0 & 12 & 4 & 1.8 & Disagree \\
\hline $\begin{array}{l}\text { Preparing a deliverable schedule } \\
\text { relative to bidding practices }\end{array}$ & 0 & 1 & 0 & 15 & 1.1 & Strongly disagree \\
\hline $\begin{array}{l}\text { I am not involved in the formation } \\
\text { stage of the construction project }\end{array}$ & 0 & 1 & 0 & 15 & 1.1 & Strongly disagree \\
\hline $\begin{array}{l}\text { Finalization and selection of } \\
\text { vendors/supplier }\end{array}$ & 0 & 0 & 0 & 16 & 1.0 & Strongly disagree \\
\hline
\end{tabular}

Involvement in the conceptualization stage of construction projects. Table 6 indicates the response of Group A managers.

It is evident that even in the conceptualization stage of construction projects, the Group A set of project managers are actively involved. This includes design, material selection, delegation of responsibility, purchase of materials, costing and financial estimations, contract management, scheduling, and goal setting (setting the mission and vision for the project).

Table 7 indicates the response of the Group B set of project managers.

Unlike in the formulation stage, where Group B was unanimous in its non-involvement, there is some involvement in the conceptualization stage. An analysis of Table 7 indicates that Group B is involved in aspects, such as schedule planning, contract management, costing, and planning for project requirements. However, in such aspects, such as goal setting, vision and mission formulation, design and conceptualization, purchase 
planning, and clarification of project scope, they are not involved. Yet, it may be noted here that it is these latter tasks that are more related to conceptualization and visualization of the entire project in its entirety.

Table 6

Conceptualization Stage-Group A

\begin{tabular}{|c|c|c|c|c|c|c|}
\hline Group A & $\begin{array}{l}\text { Strongly } \\
\text { agree: } 4\end{array}$ & Agree: 3 & Disagree: 2 & $\begin{array}{l}\text { Strongly } \\
\text { disagree: } 1\end{array}$ & $\begin{array}{l}\text { Weighted } \\
\text { average }\end{array}$ & Interpretation \\
\hline $\begin{array}{l}\text { Design and conceptualization of final } \\
\text { construction product }\end{array}$ & 4 & 0 & 0 & 0 & 4.0 & Strongly agree \\
\hline $\begin{array}{l}\text { Selection of materials, finishes, } \\
\text { specifications of projects }\end{array}$ & 3 & 1 & 0 & 0 & 3.8 & Strongly agree \\
\hline $\begin{array}{l}\text { Preparing a preliminary construction } \\
\text { schedule }\end{array}$ & 4 & 0 & 0 & 0 & 4.0 & Strongly agree \\
\hline $\begin{array}{l}\text { Delineating project requirement and } \\
\text { general conditions }\end{array}$ & 4 & 0 & 0 & 0 & 4.0 & Strongly agree \\
\hline $\begin{array}{l}\text { Purchasing of materials, finished } \\
\text { goods required for the project }\end{array}$ & 3 & 1 & 0 & 0 & 3.8 & Strongly agree \\
\hline Structure project task and clarify scope & 4 & 0 & 0 & 0 & 4.0 & Strongly agree \\
\hline $\begin{array}{l}\text { Set the vision, mission, goals, } \\
\text { objectives of the project }\end{array}$ & 4 & 0 & 0 & 0 & 4.0 & Strongly agree \\
\hline $\begin{array}{l}\text { Costing and estimation of financial } \\
\text { requirements }\end{array}$ & 4 & 0 & 0 & 0 & 4.0 & Strongly agree \\
\hline Contract management and finalization & 2 & 2 & 0 & 0 & 3.5 & Strongly agree \\
\hline Planning of schedule resources & 4 & 0 & 0 & 0 & 4.0 & Strongly agree \\
\hline $\begin{array}{l}\text { I am not involved at all during the } \\
\text { conceptualization stage of the project }\end{array}$ & 0 & 0 & 0 & 4 & 1.0 & Strongly disagree \\
\hline
\end{tabular}

Table 7

Conceptualization Stage-Group B

\begin{tabular}{|c|c|c|c|c|c|c|}
\hline Group B & $\begin{array}{l}\text { Strongly } \\
\text { agree: } 4\end{array}$ & Agree: 3 & Disagree: 2 & $\begin{array}{l}\text { Strongly } \\
\text { disagree: } 1\end{array}$ & $\begin{array}{l}\text { Weighted } \\
\text { average }\end{array}$ & Interpretation \\
\hline $\begin{array}{l}\text { Design and conceptualization of final } \\
\text { construction product }\end{array}$ & 0 & 4 & 12 & 0 & 2.3 & Disagree \\
\hline $\begin{array}{l}\text { Selection of materials, finishes, } \\
\text { specifications of projects }\end{array}$ & 0 & 10 & 2 & 4 & 2.4 & Disagree \\
\hline $\begin{array}{l}\text { Preparing a preliminary construction } \\
\text { schedule }\end{array}$ & 4 & 8 & 4 & 0 & 3.0 & Agree \\
\hline $\begin{array}{l}\text { Delineating project requirement and } \\
\text { general conditions }\end{array}$ & 10 & 4 & 2 & 0 & 3.5 & Strongly agree \\
\hline $\begin{array}{l}\text { Purchasing of materials, finished } \\
\text { goods required for the project }\end{array}$ & 0 & 1 & 15 & 0 & 2.1 & Disagree \\
\hline Structure project task and clarify scope & 0 & 2 & 14 & 0 & 2.1 & Disagree \\
\hline $\begin{array}{l}\text { Set the vision, mission, goals, } \\
\text { objectives of the project }\end{array}$ & 1 & 2 & 8 & 5 & 1.9 & Disagree \\
\hline $\begin{array}{l}\text { Costing and estimation of financial } \\
\text { requirements }\end{array}$ & 2 & 6 & 7 & 1 & 2.6 & Agree \\
\hline Contract management and finalization & 6 & 8 & 2 & 0 & 3.3 & Agree \\
\hline Planning of schedule resources & 7 & 5 & 4 & 0 & 3.2 & Agree \\
\hline $\begin{array}{l}\text { I am not involved at all during the } \\
\text { conceptualization stage of the project }\end{array}$ & 6 & 8 & 2 & 0 & 3.3 & Agree \\
\hline
\end{tabular}

Involvement in the execution stage of construction projects. Table 8 indicates the response of the Group A set of project managers.

From Table 8, it can be seen that just like in the formulation and conceptualization stages, Group A is 
actively involved in the execution stage of the construction projects as well. This includes materials allocation, co-ordination activities, supervision and monitoring, document control, manpower allocation, and holding of project meetings.

Table 8

Execution Stage-Group A

\begin{tabular}{|c|c|c|c|c|c|c|}
\hline Group A & $\begin{array}{l}\text { Strongly } \\
\text { agree: } 4\end{array}$ & Agree: 3 & Disagree: 2 & $\begin{array}{l}\text { Strongly } \\
\text { disagree: } 1\end{array}$ & $\begin{array}{l}\text { Weighted } \\
\text { average }\end{array}$ & Interpretation \\
\hline $\begin{array}{l}\text { Manpower allocation/labor } \\
\text { management }\end{array}$ & 3 & 1 & 0 & 0 & 3.8 & Strongly agree \\
\hline $\begin{array}{l}\text { Monitoring of time, quality, resource } \\
\text { utilization, costs, project progress }\end{array}$ & 4 & 0 & 0 & 0 & 4.0 & Strongly agree \\
\hline $\begin{array}{l}\text { Provide direction for progress of } \\
\text { project }\end{array}$ & 2 & 2 & 0 & 0 & 3.5 & Strongly agree \\
\hline $\begin{array}{l}\text { Scheduling of activities/movement of } \\
\text { materials }\end{array}$ & 1 & 3 & 0 & 0 & 3.3 & Agree \\
\hline Materials planning/allocation & 4 & 0 & 0 & 0 & 4.0 & Strongly agree \\
\hline $\begin{array}{l}\text { Supervision of overall plans/change } \\
\text { management }\end{array}$ & 4 & 0 & 0 & 0 & 4.0 & Strongly agree \\
\hline $\begin{array}{l}\text { Manage project } \\
\text { meetings/correspondence }\end{array}$ & 4 & 0 & 0 & 0 & 4.0 & Strongly agree \\
\hline $\begin{array}{l}\text { Conflict } \\
\text { management/troubleshooting/issue } \\
\text { resolution }\end{array}$ & 4 & 0 & 0 & 0 & 4.0 & Strongly agree \\
\hline Document control & 1 & 2 & 1 & 0 & 3.0 & Agree \\
\hline Co-ordination of activities & 4 & 0 & 0 & 0 & 4.0 & Strongly agree \\
\hline $\begin{array}{l}\text { I am not involved in the execution } \\
\text { stage of the project }\end{array}$ & 0 & 0 & 1 & 3 & 1.3 & Strongly disagree \\
\hline
\end{tabular}

Table 9 indicates the response of the Group B set of project managers.

Table 9

Execution Stage-Group B

\begin{tabular}{|c|c|c|c|c|c|c|}
\hline Group B & $\begin{array}{l}\text { Strongly } \\
\text { agree: } 4\end{array}$ & Agree: 3 & Disagree: 2 & $\begin{array}{l}\text { Strongly } \\
\text { disagree: } 1\end{array}$ & $\begin{array}{l}\text { Weighted } \\
\text { average }\end{array}$ & Interpretation \\
\hline $\begin{array}{l}\text { Manpower allocation/labor } \\
\text { management }\end{array}$ & 12 & 4 & 0 & 4 & 4.0 & Strongly agree \\
\hline $\begin{array}{l}\text { Monitoring of time, quality, resource } \\
\text { utilization, costs, project progress }\end{array}$ & 11 & 5 & 0 & 0 & 3.7 & Strongly agree \\
\hline $\begin{array}{l}\text { Provide direction for progress of } \\
\text { project }\end{array}$ & 0 & 6 & 10 & 0 & 2.4 & Disagree \\
\hline $\begin{array}{l}\text { Scheduling of activities/movement of } \\
\text { materials }\end{array}$ & 12 & 4 & 0 & 0 & 3.8 & Strongly agree \\
\hline Materials planning/allocation & 13 & 3 & 0 & 0 & 3.8 & Strongly agree \\
\hline $\begin{array}{l}\text { Supervision of overall plans/change } \\
\text { management }\end{array}$ & 10 & 2 & 4 & 0 & 3.4 & Agree \\
\hline $\begin{array}{l}\text { Manage project } \\
\text { meetings/correspondence }\end{array}$ & 8 & 8 & 0 & 0 & 3.5 & Strongly agree \\
\hline $\begin{array}{l}\text { Conflict } \\
\text { management/troubleshooting/issue } \\
\text { resolution }\end{array}$ & 10 & 6 & 0 & 0 & 3.6 & Strongly agree \\
\hline Document control & 15 & 1 & 0 & 0 & 3.9 & Strongly agree \\
\hline Co-ordination of activities & 16 & 0 & 0 & 0 & 4.0 & Strongly agree \\
\hline $\begin{array}{l}\text { I am not involved in the execution } \\
\text { stage of the project }\end{array}$ & 0 & 0 & 4 & 12 & 1.3 & Strongly disagree \\
\hline
\end{tabular}


From Table 9, it can be seen that all the project managers belonging to Group B strongly agree that they are involved in the execution stage of the construction projects. This includes the entire range and set of activities defined in the table. The only parameter where they do not appear to agree is on providing direction for the overall progress of the project. It appears that conceptual processes are left out of their purview of their responsibilities, with their scope of task heavily skewed in favor of supervision, monitoring, and allocation of men and materials.

Involvement in the completion stage of construction projects. Table 10 indicates the response of Group A managers.

Table 10

Completion Stage-Group A

\begin{tabular}{|c|c|c|c|c|c|c|}
\hline Group A & $\begin{array}{l}\text { Strongly } \\
\text { agree: } 4\end{array}$ & Agree: 3 & Disagree: 2 & $\begin{array}{l}\text { Strongly } \\
\text { disagree: } 1\end{array}$ & $\begin{array}{l}\text { Weighted } \\
\text { average }\end{array}$ & Interpretation \\
\hline Achieving substantial completion & 3 & 1 & 0 & 0 & 3.8 & Strongly agree \\
\hline Aggressive punch list completion & 4 & 0 & 0 & 0 & 4.0 & Strongly agree \\
\hline $\begin{array}{l}\text { Submission of drawings, } \\
\text { maintenance manuals, warranties }\end{array}$ & 2 & 2 & 0 & 0 & 3.5 & Strongly agree \\
\hline $\begin{array}{l}\text { Close out with sub-contractors on } \\
\text { their individuals }\end{array}$ & 1 & 3 & 0 & 0 & 3.3 & Agree \\
\hline $\begin{array}{l}\text { Preparation and validation of check } \\
\text { list }\end{array}$ & 4 & 0 & 0 & 0 & 4.0 & Strongly agree \\
\hline $\begin{array}{l}\text { Obtain customer feedback and get } \\
\text { their sign off on the project }\end{array}$ & 4 & 0 & 0 & 0 & 4.0 & Strongly agree \\
\hline $\begin{array}{l}\text { Handing over finished product to } \\
\text { customer }\end{array}$ & 4 & 0 & 0 & 0 & 4.0 & Strongly agree \\
\hline $\begin{array}{l}\text { Compare and contrast actual with } \\
\text { projections on time and cost }\end{array}$ & 4 & 0 & 0 & 0 & 4.0 & Strongly agree \\
\hline Post completion maintenance & 1 & 2 & 1 & 0 & 3.0 & Agree \\
\hline $\begin{array}{l}\text { I am not involved in the completion } \\
\text { stage of the project }\end{array}$ & 0 & 0 & 2 & 2 & 1.5 & Disagree \\
\hline
\end{tabular}

From Table 10, it is evident that even during the completion stage of the construction project, all the Group A set of project managers are actively involved. This includes check list validation, handing over finished product to customers, administrative tasks such as submission of drawings and manuals, obtaining customer feedback and checking on their satisfaction levels, comparison of actual costs and timelines vis-à-vis budgeted costs and timelines, and even overview of maintenance post completion of the project.

Table 11 indicates the involvement of Group B set of managers in the completion stage of the construction projects.

Amongst the Group B set of managers, there are some involvements in the completion stages. This includes handing over product to customers, preparation of cost sheets, maintenance, and close out with vendor partners. However, they all disagree that they are actively involved in the completion stages of the construction projects.

The findings from Tables 6-9 underscore the ambiguities that were identified in section of the literature review on the role of the project manager in construction projects. The views of Jha (2013), Hopp and Spearman (2011), Egan (2012), De Ridder and Vrijhoef (2013), Bruckmann (2013), Collins (2010), and Dave et al. (2012) all indicate focus on one or the other four aforementioned stages of construction projects. These include planning, administration, purchase, scheduling, cost control, close out, and knowledge management. 
The only voice of dissent was that of Bradley (2011) who said that given the complexity and uncertainties of modern construction projects, it is imperative that project managers be actively involved in all stages of the construction project. As against this imperative however, only four out of the 20 respondents considered in this research were involved in all the stages of the project. These four also identified themselves as leaders. The other 16 managers were not involved in all the stages of the project to an equal degree. There is a heavy skewing towards the execution stage of the project. This indicates that in India, project managers are expected to play a more important role in the operations and administration side of the construction projects rather than in conceptualization, visualization, and goal setting.

Table 11

\section{Completion Stage-Group B}

\begin{tabular}{|c|c|c|c|c|c|c|}
\hline Group B & $\begin{array}{l}\text { Strongly } \\
\text { agree: } 4\end{array}$ & Agree: 3 & Disagree: 2 & $\begin{array}{l}\text { Strongly } \\
\text { disagree: } 1\end{array}$ & $\begin{array}{l}\text { Weighted } \\
\text { average }\end{array}$ & Interpretation \\
\hline Achieving substantial completion & 8 & 4 & 0 & 4 & 3.0 & Agree \\
\hline Aggressive punch list completion & 2 & 6 & 7 & 1 & 2.6 & Agree \\
\hline $\begin{array}{l}\text { Submission of drawings, } \\
\text { maintenance manuals, warranties }\end{array}$ & 0 & 6 & 0 & 10 & 1.8 & Disagree \\
\hline $\begin{array}{l}\text { Close out with sub-contractors on } \\
\text { their individuals }\end{array}$ & 5 & 6 & 5 & 1 & 3.0 & Agree \\
\hline $\begin{array}{l}\text { Preparation and validation of check } \\
\text { list }\end{array}$ & 3 & 2 & 10 & 0 & 2.4 & Disagree \\
\hline $\begin{array}{l}\text { Obtain customer feedback and get } \\
\text { their sign off on the project }\end{array}$ & 1 & 2 & 13 & 0 & 2.3 & Disagree \\
\hline $\begin{array}{l}\text { Handing over finished product to } \\
\text { customer }\end{array}$ & 6 & 2 & 8 & 5 & 2.9 & Agree \\
\hline $\begin{array}{l}\text { Compare and contrast actual with } \\
\text { projections on time and cost }\end{array}$ & 5 & 6 & 0 & 0 & 2.7 & Agree \\
\hline Post completion maintenance & 9 & 2 & 5 & 0 & 3.3 & Agree \\
\hline $\begin{array}{l}\text { I am not involved in the completion } \\
\text { stage of the project }\end{array}$ & 3 & 4 & 6 & 3 & 2.4 & Disagree \\
\hline
\end{tabular}

However, Hilton (2010), Greenwood et al. (2013), and De Ridder (2011) in section of the literature review all agreed that while technical, operational, and administrative roles are indeed necessary and essential, it is also equally important that project managers perform a more holistic role. That is, they must be actively involved in all stages of the project and liase with all the departments and sections in order to truly make a difference. It may be inferred from this that the current view of the project managers in construction projects which is that of a "watchman" must change.

This will also be in accordance with the definitions of project management identified in the literature review where it was identified that a project is always defined in terms of budget, scope, and schedule. The literature identified all the critical success factors of construction projects. This includes client satisfaction, training, manpower competencies, management of labor, finance and logistics, clear channels of communications, and goal setting. These are elements that impact the project at all four stages of its evolution and to that extent a project manager's involvement or non-involvement in all four stages will impact the effectiveness of the end project in terms of cost, time, quality, and customer satisfaction. What must be noted also is that those managers who considered themselves as leaders were actively involved across all four stages of the construction projects, while the other managers focused almost exclusively on monitoring operations during the execution stage only. 
The next four questions will test the respondents as to what in their opinion is the most important skill for a project manager.

Management skills for a project manager. Table 12 indicates the management skills necessary for a project manager.

Table 12

Management Skills-Group A

\begin{tabular}{lllllll}
\hline Group A & $\begin{array}{l}\text { Strongly } \\
\text { agree: } 4\end{array}$ & Agree: 3 & Disagree: 2 & $\begin{array}{l}\text { Strongly } \\
\text { disagree: } 1\end{array}$ & $\begin{array}{l}\text { Weighted } \\
\text { average }\end{array}$ & Interpretation \\
\hline Time management & 4 & 0 & 0 & 0 & 4.0 & Strongly agree \\
Quality management & 4 & 0 & 0 & 0 & 4.0 & Strongly agree \\
Contract management & 3 & 1 & 0 & 0 & 3.8 & Strongly agree \\
Inventory management & 4 & 0 & 0 & 0 & 4.0 & Strongly agree \\
Resource allocation and management & 2 & 2 & 0 & 0 & 3.5 & Strongly agree \\
Safety and security management & 1 & 2 & 1 & 0 & 3.0 & Agree \\
Financial management skills & 4 & 0 & 0 & 0 & 4.0 & Strongly agree \\
Stress management skills & 3 & 1 & 0 & 0 & 3.8 & Strongly agree \\
None of the above & 0 & 0 & 0 & 4 & 1.0 & Strongly disagree \\
\hline
\end{tabular}

From Table 12, it can be seen that the Group A managers have rated all the management skills as being very important. These include the ability to manage time, quality, inventories, resource allocation, finances, as well as such factors as stress, safety, and security.

Table 13 indicates the response from Group B managers.

Table 13

Responses From Group B Managers

\begin{tabular}{lllllll}
\hline Group B & $\begin{array}{l}\text { Strongly } \\
\text { agree: } 4\end{array}$ & Agree: 3 & Disagree: 2 & $\begin{array}{l}\text { Strongly } \\
\text { disagree: } 1\end{array}$ & $\begin{array}{l}\text { Weighted } \\
\text { average }\end{array}$ & Interpretation \\
\hline Time management & 15 & 1 & 0 & 0 & 3.9 & Strongly agree \\
Quality management & 14 & 2 & 0 & 0 & 3.9 & Strongly agree \\
Contract management & 4 & 8 & 2 & 2 & 2.9 & Agree \\
Inventory management & 5 & 6 & 3 & 2 & 2.9 & Agree \\
Resource allocation and management & 2 & 3 & 5 & 6 & 2.1 & Disagree \\
Safety and security management & 0 & 3 & 7 & 6 & 1.8 & Disagree \\
Financial management skills & 8 & 2 & 1 & 5 & 2.8 & Agree \\
Stress management skills & 0 & 2 & 4 & 10 & 1.5 & Disagree \\
None of the above & 0 & 0 & 0 & 16 & 1.0 & Strongly disagree \\
\hline
\end{tabular}

It is evident from Table 13 that the Group B managers consider some management skills as being more important than others. These pertain to management of time, quality, contracts, inventory, and finance. However, they do not agree that such aspects, such as stress management, safety and security management, and allocation of resources or delegation of powers, are important for project managers.

Technical skills for a project manager. Table 14 indicates the response from Group A managers.

From Table 14, it can be seen that all the technical skills have been rated as being most important by the Group A managers. This includes computer skills, project management tools, technical tools, as well as knowledge of construction equipment. Table 15 indicates the response from Group B managers. 
Table 14

\section{Responses From Group A Managers}

\begin{tabular}{|c|c|c|c|c|c|c|}
\hline Group A & $\begin{array}{l}\text { Strongly } \\
\text { agree: } 4\end{array}$ & Agree: 3 & Disagree: 2 & $\begin{array}{l}\text { Strongly } \\
\text { disagree: } 1\end{array}$ & $\begin{array}{l}\text { Weighted } \\
\text { average }\end{array}$ & Interpretation \\
\hline $\begin{array}{l}\text { Awareness of technology and } \\
\text { techniques }\end{array}$ & 1 & 3 & 0 & 0 & 3.3 & Agree \\
\hline $\begin{array}{l}\text { Ability to understand technical } \\
\text { drawing and project design }\end{array}$ & 4 & 0 & 0 & 0 & 4.0 & Strongly agree \\
\hline $\begin{array}{l}\text { Basic knowledge of construction } \\
\text { equipment }\end{array}$ & 2 & 2 & 0 & 0 & 3.5 & Strongly agree \\
\hline Strong computer skills & 4 & 0 & 0 & 0 & 4.0 & Strongly agree \\
\hline $\begin{array}{l}\text { Advance knowledge of PM tools like } \\
\text { PERT, CPM }\end{array}$ & 4 & 0 & 0 & 0 & 4.0 & Strongly agree \\
\hline None of the above & 0 & 0 & 0 & 4 & 1.0 & Strongly disagree \\
\hline
\end{tabular}

Table 15

Responses From Group B Managers

\begin{tabular}{|c|c|c|c|c|c|c|}
\hline Group B & $\begin{array}{l}\text { Strongly } \\
\text { agree: } 4\end{array}$ & Agree: 3 & Disagree: 2 & $\begin{array}{l}\text { Strongly } \\
\text { disagree: } 1\end{array}$ & $\begin{array}{l}\text { Weighted } \\
\text { average }\end{array}$ & Interpretation \\
\hline $\begin{array}{l}\text { Awareness of technology and } \\
\text { techniques }\end{array}$ & 2 & 8 & 5 & 1 & 2.7 & Agree \\
\hline $\begin{array}{l}\text { Ability to understand technical } \\
\text { drawing and project design }\end{array}$ & 2 & 9 & 3 & 4 & 2.8 & Agree \\
\hline $\begin{array}{l}\text { Basic knowledge of construction } \\
\text { equipment }\end{array}$ & 5 & 9 & 2 & 0 & 3.2 & Agree \\
\hline Strong computer skills & 4 & 4 & 6 & 2 & 2.6 & Agree \\
\hline $\begin{array}{l}\text { Advance knowledge of PM tools like } \\
\text { PERT, CPM }\end{array}$ & 8 & 4 & 3 & 1 & 3.2 & Agree \\
\hline None of the above & 0 & 0 & 0 & 16 & 1.0 & Disagree \\
\hline
\end{tabular}

Like the Group A managers, the Group B managers are unanimous that project managers should possess strong technical skills as can be seen in Table 15.

Interpersonal skills for a project manager. Table 16 indicates the views of Group A managers towards interpersonal skills.

Table 16

Interpersonal Skills-Group A Managers

\begin{tabular}{|c|c|c|c|c|c|c|}
\hline Group A & $\begin{array}{l}\text { Strongly } \\
\text { agree: } 4\end{array}$ & Agree: 3 & Disagree: 2 & $\begin{array}{l}\text { Strongly } \\
\text { disagree: } 1\end{array}$ & $\begin{array}{l}\text { Weighted } \\
\text { average }\end{array}$ & Interpretation \\
\hline Issue resolution & 3 & 1 & 0 & 0 & 3.8 & Strongly agree \\
\hline Strong networking and liasoning skill & 4 & 0 & 0 & 0 & 4.0 & Strongly agree \\
\hline $\begin{array}{l}\text { Ability to articulate project } \\
\text { objectives to team }\end{array}$ & 4 & 0 & 0 & 0 & 4.0 & Strongly agree \\
\hline Communication skills & 4 & 0 & 0 & 0 & 4.0 & Strongly agree \\
\hline $\begin{array}{l}\text { Ability to negotiate with customers, } \\
\text { supervisors }\end{array}$ & 4 & 0 & 0 & 0 & 4.0 & Strongly agree \\
\hline $\begin{array}{l}\text { Co-ordinating ability amongst } \\
\text { different }\end{array}$ & 2 & 2 & 0 & 0 & 3.5 & Strongly agree \\
\hline Delegation skills & 1 & 3 & 0 & 0 & 3.3 & Agree \\
\hline None of the above & 0 & 0 & 0 & 4 & 1 & Strongly disagree \\
\hline
\end{tabular}

Interpersonal skills have been rated very high by all the managers. These include the ability to resolve various issues, networking and communication skills, the ability to negotiate with vendor partners, co-ordinate 
with different stakeholders, and the ability to delegate as well.

Table 17 indicates the views of Group B managers on interpersonal skills.

From Table 17, it would see from the Group B set of manager's rate that some interpersonal skills are more important than others. Thus skills like conflict resolution, the ability to network and communicate, and negotiation skills have been rated as being important. However, the managers reported that the ability to achieve co-ordination amongst different stakeholders and delegation skills is not important. This points to a somewhat authoritarian style of functioning.

Table 17

Interpersonal Skills—Group B Managers

\begin{tabular}{|c|c|c|c|c|c|c|}
\hline Group B & $\begin{array}{l}\text { Strongly } \\
\text { agree: } 4\end{array}$ & Agree: 3 & Disagree: 2 & $\begin{array}{l}\text { Strongly } \\
\text { disagree: } 1\end{array}$ & $\begin{array}{l}\text { Weighted } \\
\text { average }\end{array}$ & Interpretation \\
\hline Issue resolution & 11 & 5 & 0 & 0 & 3.7 & Strongly agree \\
\hline Strong networking and liasoning skill & 2 & 8 & 5 & 1 & 2.7 & Agree \\
\hline $\begin{array}{l}\text { Ability to articulate project } \\
\text { objectives to team }\end{array}$ & 6 & 2 & 4 & 4 & 2.6 & Agree \\
\hline Communication skills & 7 & 4 & 4 & 0 & 3.0 & Agree \\
\hline $\begin{array}{l}\text { Ability to negotiate with customers, } \\
\text { supervisors }\end{array}$ & 11 & 5 & 0 & 0 & 3.7 & Strongly agree \\
\hline $\begin{array}{l}\text { Co-ordinating ability amongst } \\
\text { different }\end{array}$ & 1 & 4 & 10 & 2 & 2.4 & Disagree \\
\hline Delegation skills & 3 & 2 & 8 & 3 & 2.3 & Disagree \\
\hline None of the above & 0 & 0 & 7 & 9 & 1.4 & Strongly disagree \\
\hline
\end{tabular}

An analysis of the mentioned sections indicates that the Group A managers believed that project managers must necessarily possess managerial, technical, interpersonal, and human skills. However, the Group B set of managers emphasize more on technical skills rather than any of the other skills. This is not to state that the Group B managers do not believe that project managers should not have managerial, interpersonal, or human skills. However, they rate the technical skills as being far more important and even sufficient for a project manager to possess. When contrasted with the roles they play in construction projects, namely that of operations during the execution stage, this attitude may be better understood. Nevertheless, it only underscores why the Group B set of managers cannot be considered to be leaders, whilst the Group A set of managers may be.

The mentioned literature identified the qualities that a project manager who is also a leader must possess. It is important for the project manager to be well experienced, qualified, and technically competent. However, it is also equally important for the project manager to possess good communication, delegation, influencing, team building, problem solving, conflict resolution, planning and goal setting, visioning, and human skills. This must be viewed from the prism of the overall objectives of construction projects. These include achieving customer satisfaction on the one hand and profitability and market share on the other. The achievement of these objectives cannot depend on any specific sets of technical skills alone but a combination of skills. These have been outlined by Bhagwat (2012), Chua et al. (1999), De Ridder (2011), and Drucker (2010) who also stated that managers who possess these combinations of skills and competencies then guide the organization towards achievement of goals. Such a person is also a leader whose main task is accomplishment of organizational goals.

It is obvious that the Group A set of managers possessed all these skills and competencies as compared to the Group B set of managers who emphasized more on technical competence. Whether this has any bearing on the effectiveness of the construction project will next be examined. 


\section{Section C-Effectiveness of Project Management}

This section measures the effectiveness of project management measured in terms of time, cost, quality, and customer satisfaction

Quality. The respondents were asked to indicate the average percentage differences that occur between the finally accepted design and the final product that was constructed. Figure 6 indicates the response of the Group A set of managers.

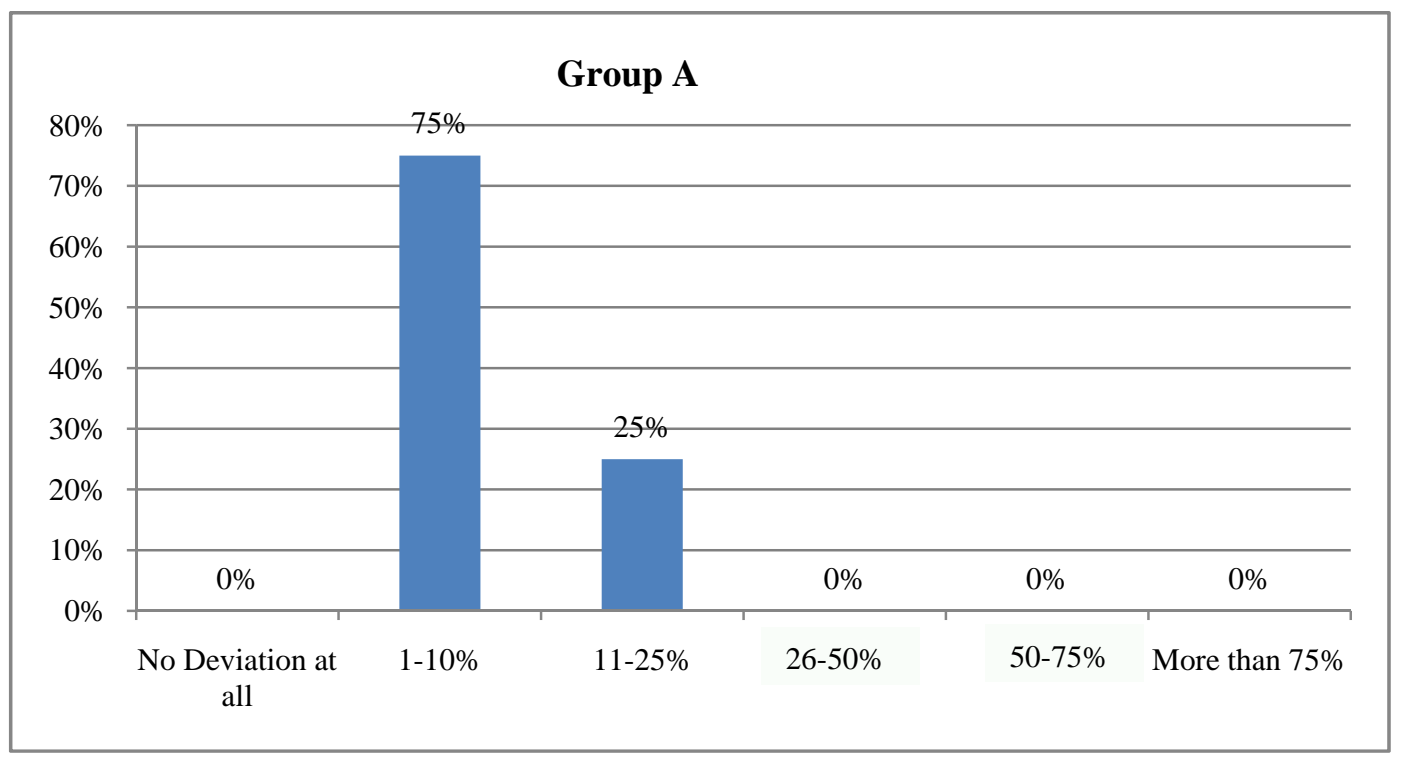

Figure 6. Group A-Quality.

It can be seen that none of the respondents indicated that there was no deviation at all. Seventy-five percent of them said that there was approximately a $10 \%$ deviation from finally accepted designs with the remaining $25 \%$ said that the extent of deviation extended from $11 \%$ to $25 \%$.

Figure 7 indicates the response of Group B set of managers.

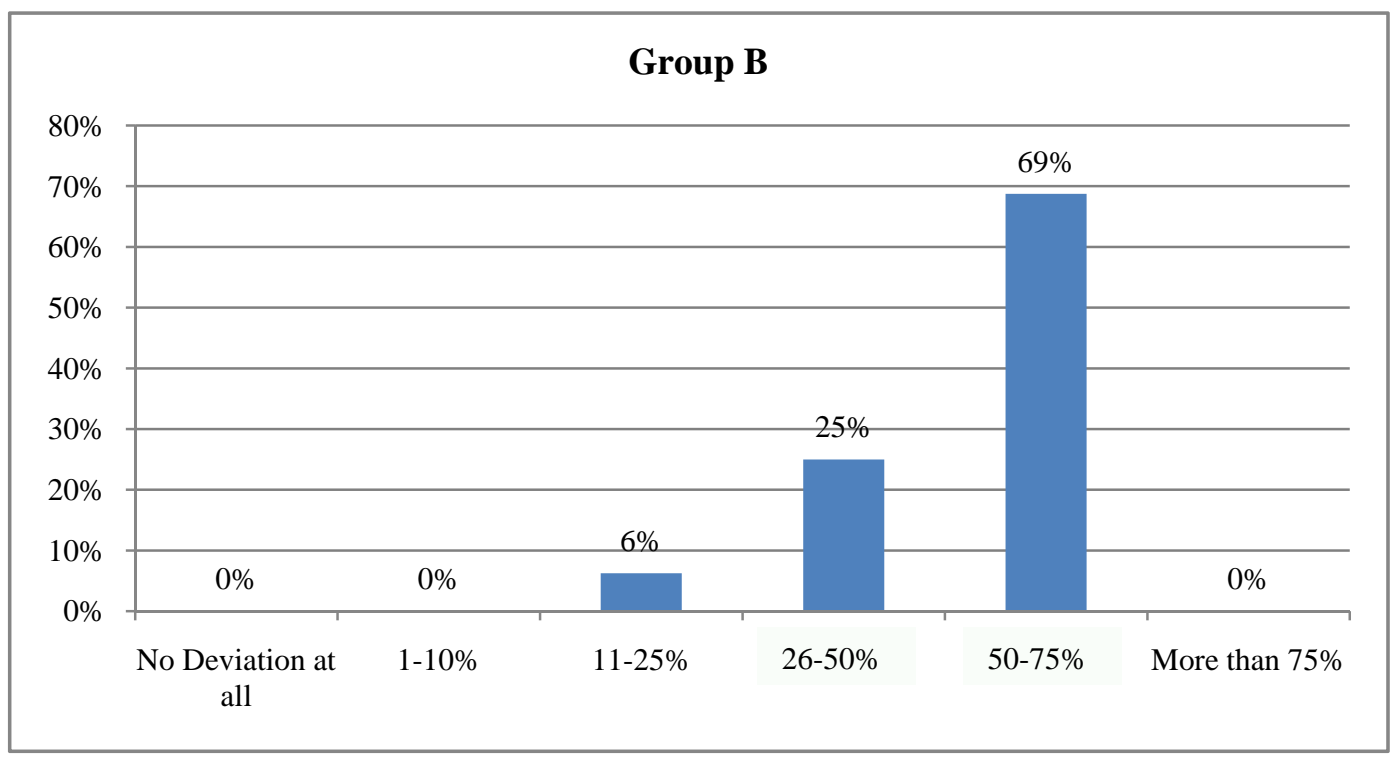

Figure 7. Group B-Quality. 
It can be seen that $69 \%$ of the Group B set of managers indicate deviations in final design in the range of $50 \%$ to $75 \%$ with $31 \%$ of them reporting deviations from $6 \%$ to $25 \%$ from final designs.

What may be noted here is that while both groups indicate a deviation from final design, the extent of deviation is more amongst Group B set of managers as compared to Group A set of managers.

Timeliness. Figures 8 and 9 indicate the response of Group A and Group B managers respectively with respect to the query on whether on an average, the time of their respective production completion cycles has increased, decreased, or remained the same.

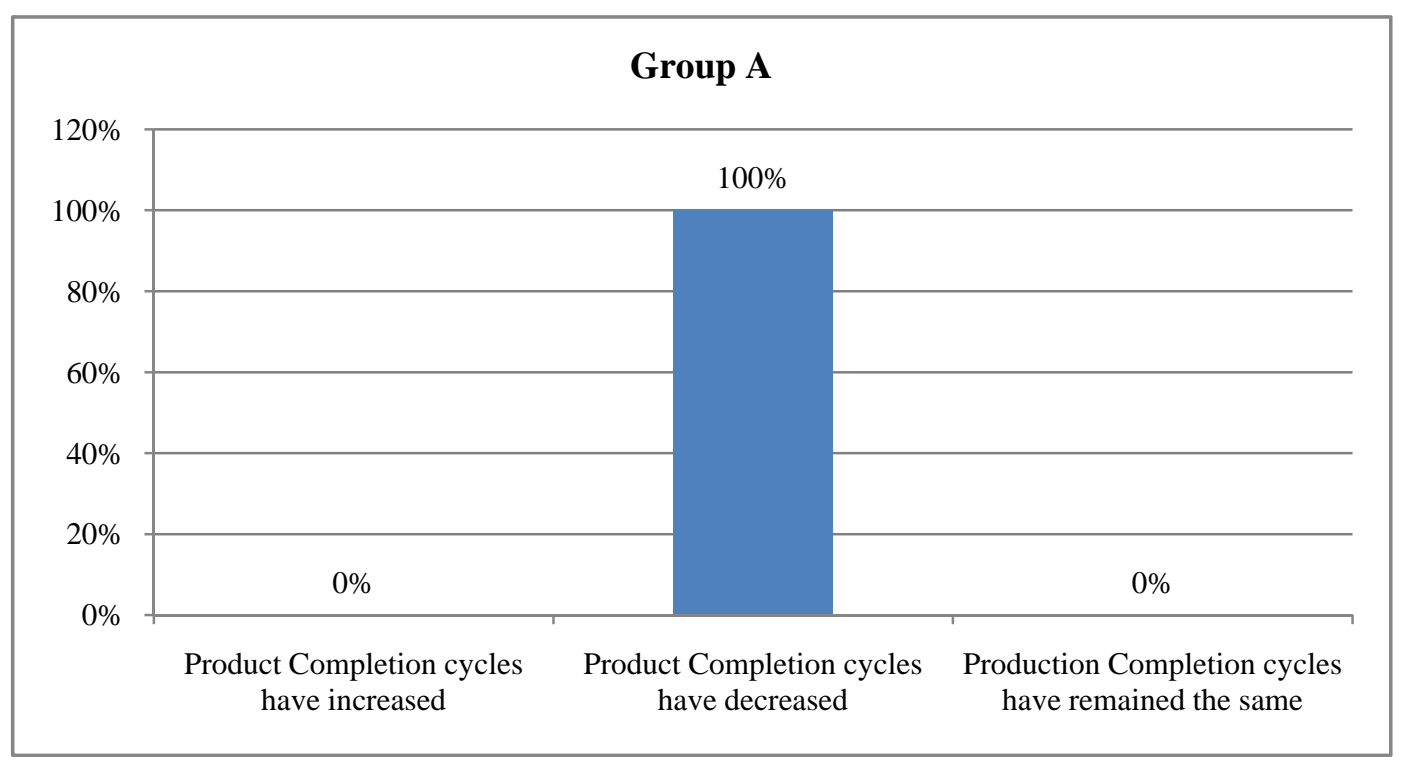

Figure 8. Group A-Timeliness.

It can be seen from Figure 8 that all the Group A managers indicate that their product completion cycles have decreased.

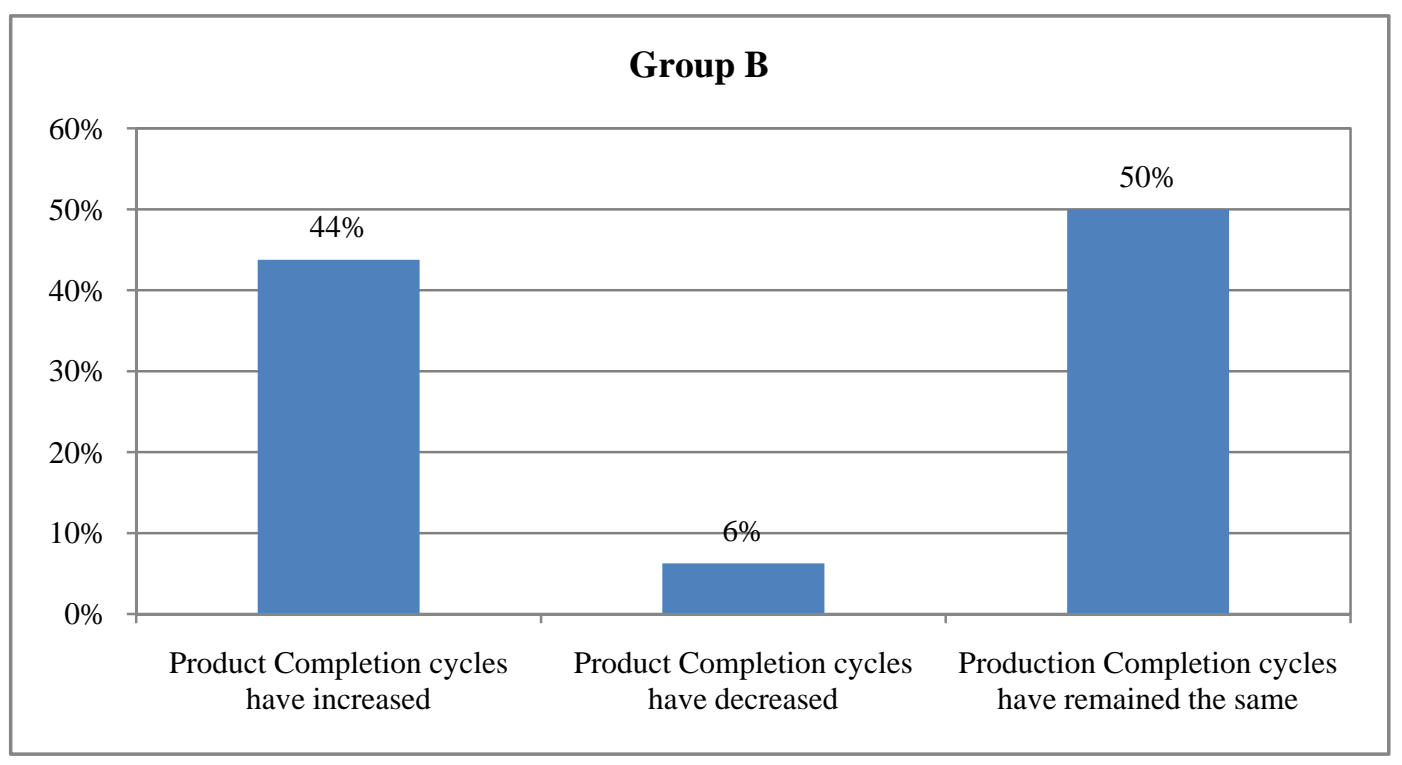

Figure 9. Group B-Timeliness. 
From Figure 9, a mixed response is evident. Only 6\% state that their product cycles have decreased. Fifty percent state that their product cycles have remained the same, while $44 \%$ state that their product completion cycles have in fact increased.

The inference here is that even against the parameter of timeliness, it is project managed by Group A set of managers which is completed in more timely fashion as compared to Group B set of managers.

Costs. Figure 10 indicates Group A set of managers response towards cost control.

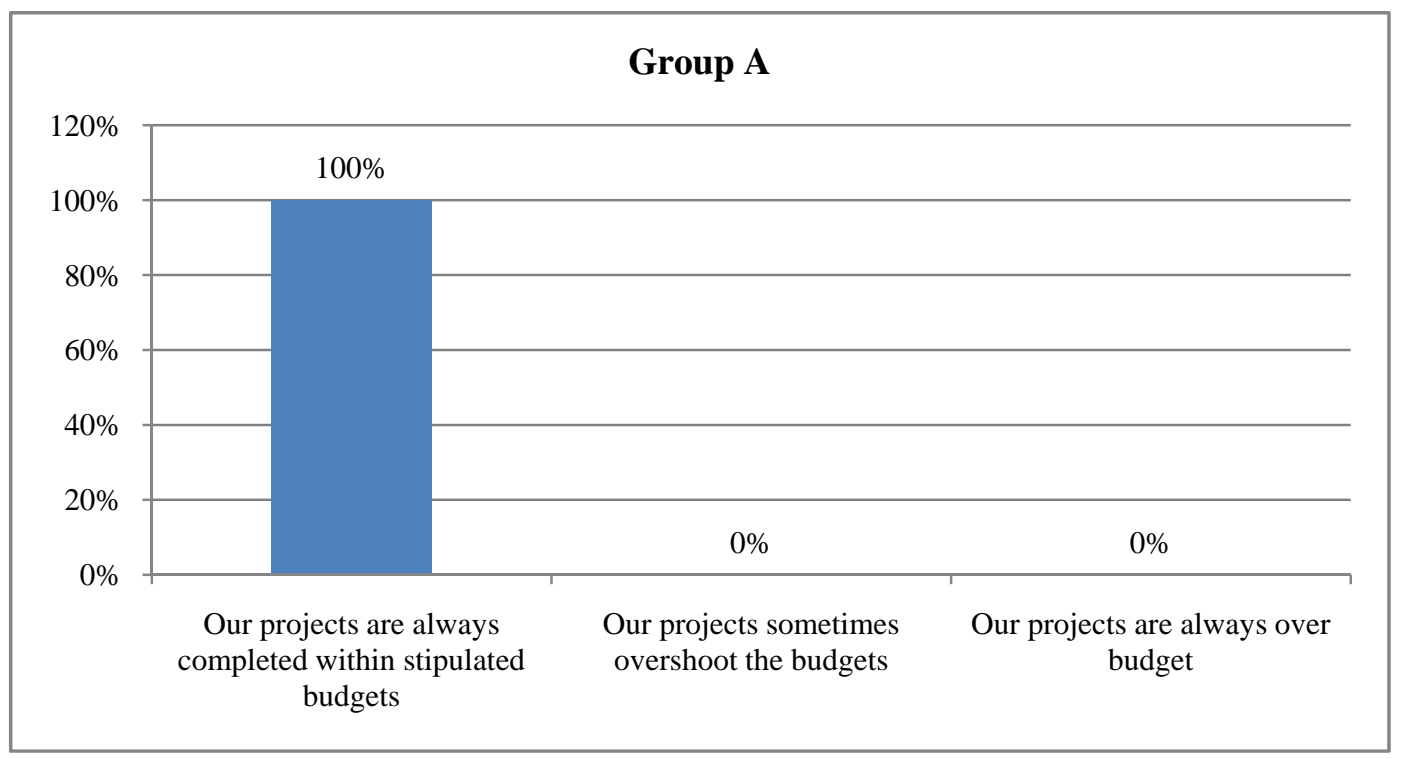

Figure 10. Group A managers-Cost control.

As can be seen from Figure 10, all the managers unanimously report that they finish their projects within stipulated budgets.

Figure 11 indicates the response of Group B managers.

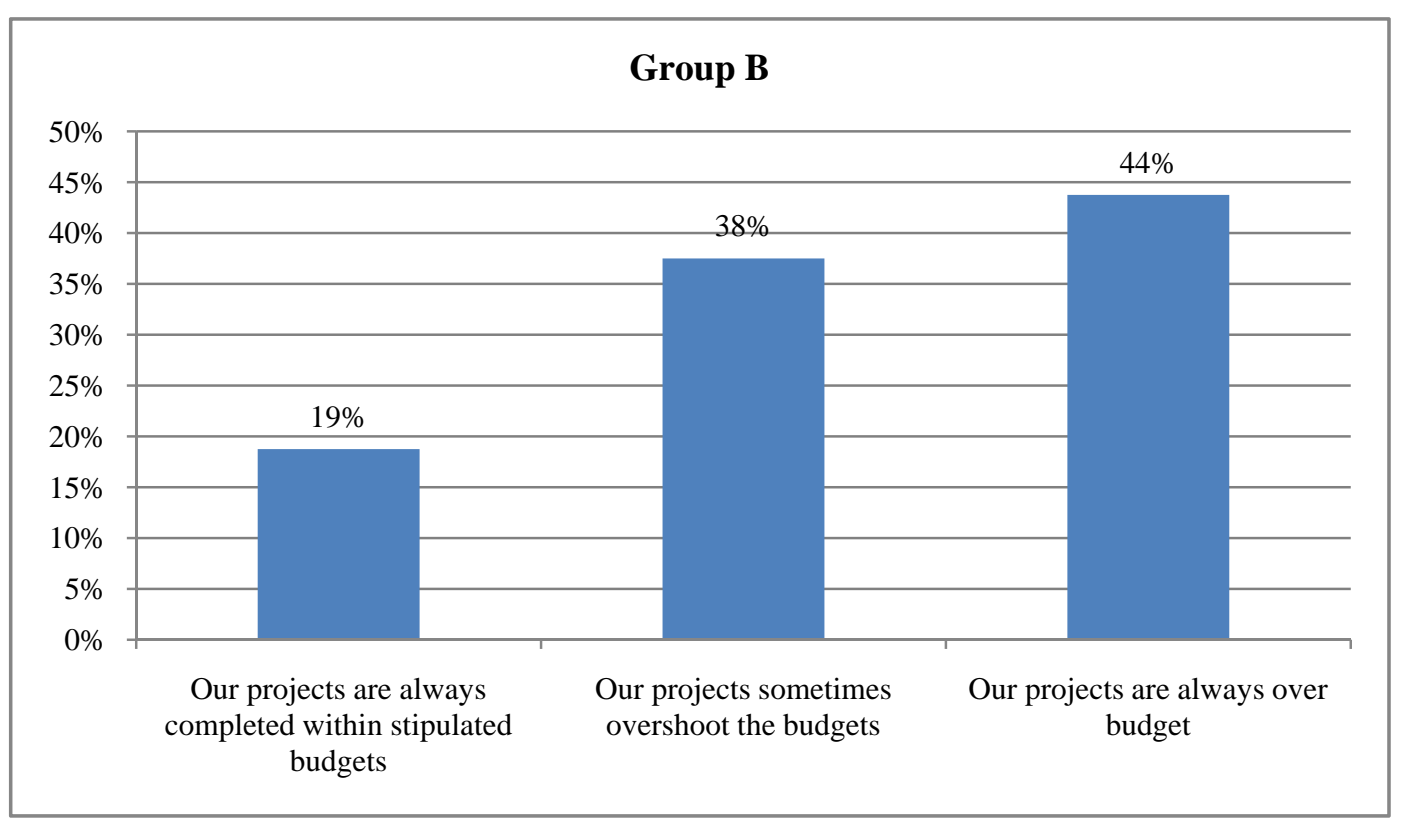

Figure 11. Group B managers-Cost control. 
Only 19\% of Group B managers indicated that they finish their projects within stipulated budgets. Thirty-eight percent said that they sometimes encounter cost overruns, while as many as $44 \%$ said that their projects invariably overshoot budgets.

Customer satisfaction. Figure 12 indicates customer satisfaction levels amongst Group A managers.

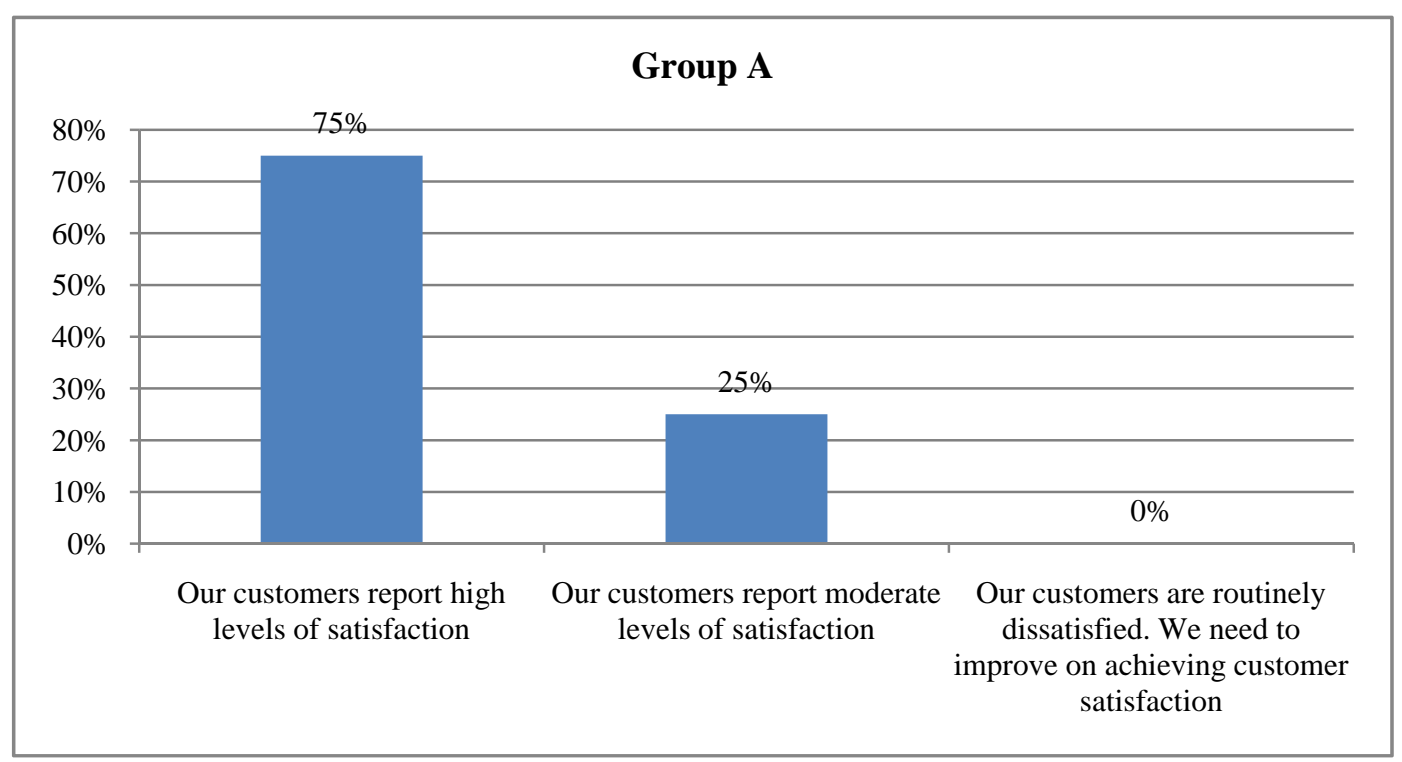

Figure 12. Customer satisfaction-Group A.

It can be seen from Figure 12 that $75 \%$ of the respondents indicated that their customers report high levels of satisfaction with $25 \%$ of them reporting only moderate levels of satisfaction.

Figure 13 indicates response of Group B managers.

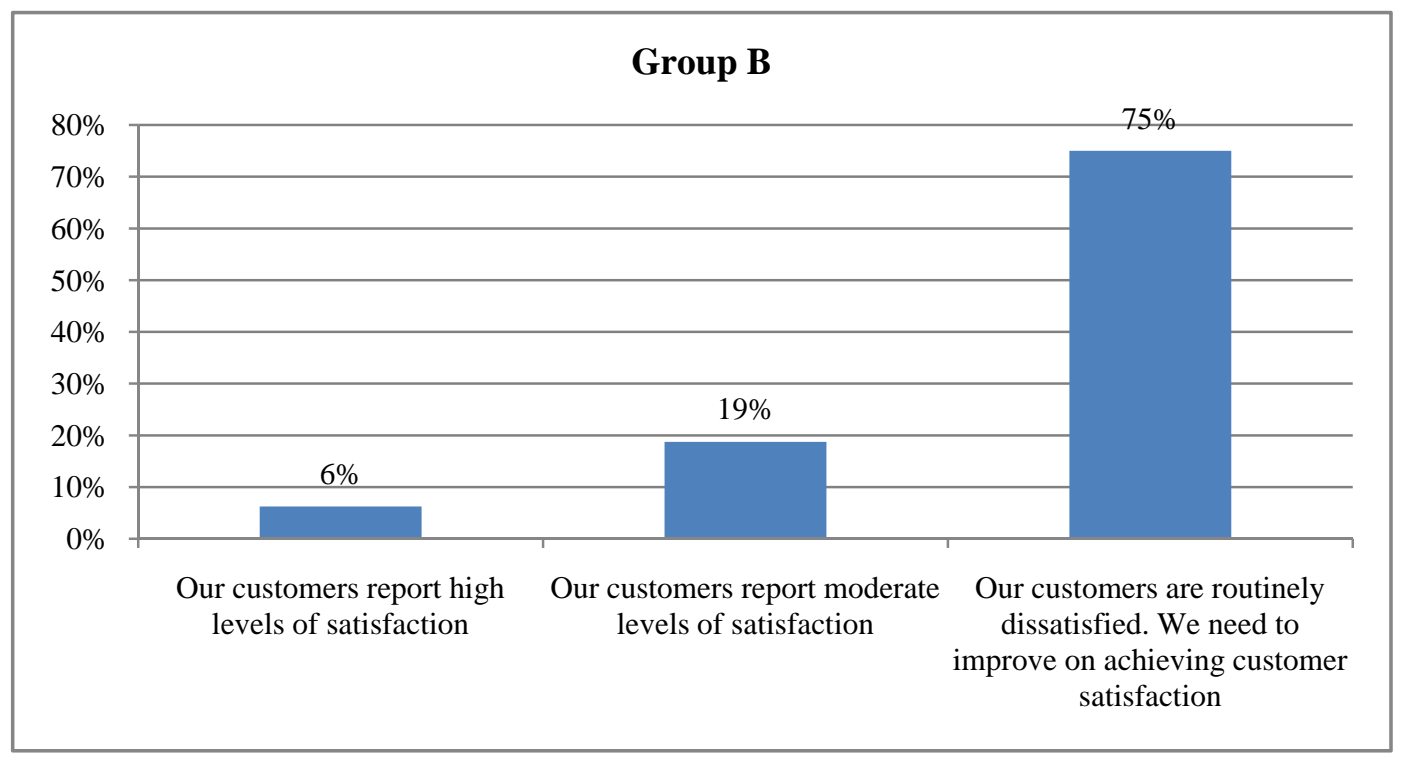

Figure 13. Customer satisfaction-Group B.

Only $6 \%$ of respondents indicated that their customers report high levels of customer satisfaction. Nineteen percent of the respondents indicated that their customers report moderate levels of customer 
satisfaction with as many as $75 \%$ of respondents indicating that their customers routinely express dissatisfaction and they need to work on improving customer satisfaction levels.

The results indicated in mention sections only serve to validate links between project managers and performance of construction projects identified in literature review. Insofar as the performance of a project is measured in terms of time, cost, quality, and customer satisfaction, the projects handled by the Group A set of managers are far more effective than the set of projects managed by the Group B set of managers. Incidentally, it is the former group who identify themselves as leaders as compared to the latter group.

\section{Conclusions}

The main objective of this research was to examine whether or not a project manager assumes a leadership role in construction projects in India. The construction industry in India is at a cross road. Posting the liberalization of the country in 1991, India has witnessed a construction boom as rapid industrialization and urbanization creates an urgent need to improve infrastructure and provide for housing and commercial spaces. However, it was identified in the literature that if the construction industry is to leverage this boom in construction activity, it will have to counter many challenges. Not the least of these is the achievement of customer satisfaction. Key to achieving customer satisfaction is delivering the construction product within the required timelines, at or within the projected costs, and at the stipulated quality. Customer satisfaction is important, because this is what creates customer loyalty and good word of mouth marketing all of which translates into increased business, turnover, profitability, and market share for the construction firm. This is as true in India as it is in the rest of the world and other business sectors as well.

It is in light of these challenges that project management assumes significance. Indeed, the very first aim of this research was to ascertain the importance or the significance of a project manager. From the literature, it was identified that assigning a project manager on construction projects plays an important role in stream operations and ensuring that the objectives of the construction firm are achieved. Significant benefits were found to accrue on those projects which had a project manager as opposed to those projects which were managed without a project manager. The project manager was found to be the fulcrum around which the entire project revolves or the glue that sticks together each and every element of a construction project. It is because of this that the project manager may also be considered to be the leader of a project far more so than the end client or the owners/other managers of the construction firm. From the questionnaire survey administered to the 20 project managers in India, it was found that all of them were well experienced individuals with professional qualifications. It is evident that the construction sector in India recognizes the importance of project management and hires well qualified talent as project managers.

Having established the importance of project management, another aim was to understand the role that project managers actually play in construction projects. Here the analysis was conducted according to those managers who considered themselves at the helm of affairs with respect to their projects and were leaders and those who did not consider themselves to be leaders. It was found that amongst the former group, there was involvement in all the four stages of construction projects, including formulation, conceptualization, execution, and completion. Amongst the latter group, which was the majority group, the managers were all exclusively focusing on activities concerning the execution stage. This includes mainly adopting a supervisory or monitoring role rather than a holistic role, including goal setting, vision and mission formulation, planning, labor management, and relationship management. From this, it may be inferred that though the Indian 
construction industry recognizes the importance of project management and of project managers, the actual roles and responsibilities assigned to them are relegated only to a part rather than the whole project.

Another aim of this project was to ascertain the competencies of project managers. Amongst those managers who considered themselves to be leaders, there was equal importance accorded to technical, managerial, interpersonal, and human skills. However, while the other managers did not belittle the importance of the other skills, they focused almost exclusively on technical skills which were rated as being most important. However, from the literature, it was identified that if a manager was to be recognized as a leader, he/she must possess all those skills that relate to each and every aspect of the project. These include liasing, counseling and negotiating skills, technical competencies, and managerial skills related to management of time, cost, quality, inventory, as well as vendor/customer management among others. It is only such managers who will be able to assume the position at the helm of affairs of projects and guide these projects towards fulfillment of objectives.

A last critical aim was to ascertain any differences in performance in those projects where project managers were also leaders and in those projects where project managers did not hold positions of leadership. It was found from the questionnaire that against all the parameters of time, cost, quality, and customer satisfaction, those projects where project managers were leaders outperformed those where the project managers performed operations roles only.

It may therefore be concluded that project managers in construction projects must necessarily be leaders. This is particularly true of India, where project managers seem to be relegated to one or other task only rather than be involved in the entire projects and possessing a holistic set of skills and competencies. The hypotheses identified in the methodology chapter also stand validated. The more the project manager assumes a leadership role, the more cost efficient the project becomes. Timelines are adhered to and quality is enhanced. In addition, productivity of the labor force is improved and the turnover, profitability, and market share of the firm enhanced.

\section{Future Scope of the Research}

This research only evaluated the performance of construction project managers against the parameters of cost, time, quality, and customer satisfaction. However, from the literature, other parameters were also established. These include productivity per man hour, job satisfaction levels, company turnover, and level of absenteeism/attrition rates as criteria. These metrics need to be further examined to establish the true scope of the role of project managers in construction projects.

How the transition from an operation role to a leadership role is to be achieved and also offers future scope of study. In addition, which particular competency is more important as compared to the others, within the overall skill and competency sets ascertained, needs to be better understood.

If in India, there is overwhelming focus on the execution stage of a construction project, adequate research needs to be done. Perhaps, this is the weakest area in Indian construction projects which needs the exclusive attention of qualified project managers. This needs to be better understood.

\section{References}

Abdel-Razek, R. H. (2012). Quality improvement in construction: Methodology and implementation. ASCE Journal of Construction Engineering and Management, 124(5), 354-360.

Arditi, D., \& Gunaydin, H. M. (2011). Factors that affect process quality in the life cycle of building projects. ASCE Journal of Construction Engineering and Management, 124(3), 194-203. 
Austin, S. A., \& Thompson, D. S. (2012). Integral value engineering in design. Proceedings from COBRA Conference 2012, RICS, Manchester.

Barnes, M. (2011). Construction project management (Construction Project Management, London, UK).

Berends, T. C. (2007). Contracting economics of large engineering and construction projects. New York: MacMillan Press.

Bhagwat, R. (2012). Construction management practices. Computers \& Industrial Engineering, 53(1), 43-62.

Bradley, P. (2011). Project management-The way ahead. M\&E Co-ordination. Building Services Journal, 2, 2-18.

Bresnen, M., \& Marshall, N. (2010). Cultural change in construction: Developing the project managers role to improve project performance. Swindon: Innovative Manufacturing Research Center.

Brezet, H. (2012). Sustainable product management. Towards sustainable product design conference. London: The Centre for Sustainable Design.

Brown, D., Dillard, J., \& Marshall, S. (2009). Triple bottom line: A business metaphor for a social construct. Retrieved from http://www.sba.pdx.edu/faculty/darrellb/dbaccess/MIM/TBL.pdf

Bruckmann, C. (2013). Construction management (Aalborg University, Sweden).

Bubshait, A. A., \& Al-Atiq, T. H. (2011). ISO 9000 quality standards in construction. ASCE Journal of Management in Engineering, 15(6), 41-46.

Bunn, R., \& Smith, T. (2013). Leadership in project management. Building Services Journal, 8, 23-42.

Burdge, R. J., \& Robertson, R. A. (2009). The role of the project manager in construction projects. Environmental Impact Assessment Review, 10, 81-90.

Chua, D. K. H., Kog, Y. C., \& Loh, P. K. (1999). Critical success factors for different project objectives. ASCE Journal of Construction Engineering and Management, 125(3), 142-150.

CIRIA. (2013). Leadership for project managers (Design Manual, SP134-CIRIA, London).

Collins, F. C. (2010). Quality in construction: The ball in your court. New York: Tata McGraw-Hill.

Crittenden, B. (2012). A practical guide to project management. New York: McGraw \& Hill.

Dave, B., Koskela, L., Kagioglou, M., \& Bertelsen, S. (2012). A critical look at integrating people, process and information technology within the construction industry. Proceedings from the 16th Annual Conference of the International Group for Lean Construction IGLC16, University of Salford, Manchester.

De Ridder, H. A. J. (2011). Living building concept for market dynamics, innovation and sustainable buildings. Proceedings from WCPM2007 Conference, Delft University of Technology.

De Ridder, H., \& Vrijhoef, R. (2013). Developing a value-price-cost leverage model for integrated value chain and life cycle management of built objects. Proceedings from CIB Student Chapters Symposium, Hong Kong.

Deming, W. E. (2012). Out of the crisis. Cambridge: The MIT Press.

Drucker, P. F. (2010). Concept of the corporation. Boston: Beacon Press.

Egan, J. (2012). Rethinking construction in the India (Construction Task Force, India Department of the Environment Transport and the Regions HMSO, London).

Formoso, C. T., \& Soibelman, L. (2012). Material waste in building industry: Main causes and prevention. Journal of Construction Engineering and Management, 128(4), 316-325.

Greenwood, R., Jones, P., \& Snow, C. (2013). Construction waste minimization. London: Good Practice Guide.

Grover, K., \& Somaya, B. (2011). India's top builders: The prestige group. Bangalore: Construction World.

Hague, P. (1987). The industrial market research handbook. London: Kogan Press.

Hills, M. J., Fox, P., Fong, S. W., \& Skitmore, M. (2011). The role of project managers in the construction industry. Proceedings from AACE International, Toronto, Canada.

Hilton, C. (2010). Lean construction: A new paradigm for managing construction. Proceedings from AACE International, Toronto, Canada.

Hopp, W. J., \& Spearman, M. L. (2011). Factory physics. Chicago: Irwin.

Jha, K. N. (2013). Factors for the success of a construction project: An empirical study (Doctoral thesis, Indian Institute of Technology, Delhi, India).

Kamara, J. M. (2012). Capturing client requirements in construction projects. London: Thomas Telford.

Kwakye, A. (2012). Fast track construction (CIOB occasional paper, Chartered Institute of Building, Ascort, UK).

Love, P. E. D., \& Smith, J. (2013). Benchmarking, benchaction, and benchlearning: Rework mitigation in projects. ASCE Journal of Management in Engineering, 19(4), 147-159. 
McDonald, B., \& Smithers, M. (2012). Implementing a leadership plan during the construction phase of a project. Journal of construction management economics, 16(1), 71-78.

Motete, L., Mbachu, J., \& Nkado, R. (2011). Investigations into material wastage on building sites. Proceedings from CIDB 1st Postgraduate Conference, South Africa.

Paritosh, M. (2009). Lean in construction. Mumbai: BMGI.

Rischmoller, L., \& Alarcon, L. F. (2011). Improving value generation in the design process of construction projects. Journal of Management in Engineering, 22(2), 52-60.

Saaty, T. L. (1999). Decision making for leaders: The analytic hierarchy process for decisions in a complex world. Pittsburgh, Pennsylvania: RWS Publications.

Sabol, L. (2009). Technology, change, and the building industry. New Delhi: Real Estate Review.

Sami Consulting. (2013). 2020 vision: The future of UK construction. Retrieved from http://www.samiconsulting.co.uk/2constructionskills.html

Schonberger, R. J. (2009). World class manufacturing: The next decade. New York: The Free Press.

Shen, L. Y., Tam, V., Tam, C. M., \& Drew, D. (2012). Mapping approach for project management on construction sites. Journal of Construction Engineering and Management, 130(4), 472-481.

Skoyles, E. R. (2011). Project management on site. London: Mitchell Publications.

Teo, M., \& Loosemore, M. (2011). Project management in the construction industry. Journal of Construction Management and Economics, 19, 741-751.

Tulke, J., Nour, M., \& Beucke, K. (2012). A dynamic framework for construction scheduling based on BIM. Boston: Stewart Books.

Turner, R. (2012). Construction economics and building design. New York: Van Nostrand Reinhold.

Wand, F., \& Hannafin, M. J. (2012). Design-based research and technology-enhanced learning environments. Educational Technology Research \& Development, 53(4), 5-23.

Wegner, T. (2010). Applied business statistics. Methods and applications. Cape Town: JUTA Company.

Womack, J. P., \& Jones, D. T. (2012). Lean thinking: Banish waste and create wealth in your corporation. London: Simon \& Schuster.

Zikmund, W. G., Babin, B. J., Carr, J. C., \& Griffin, M. (2010). Business research methods (8th ed.). Mason, HO: Cengage Learning. 